П.В. ЛОГИНОВ, А.А. НИКОЛАЕВ

Cejen в roppekily.

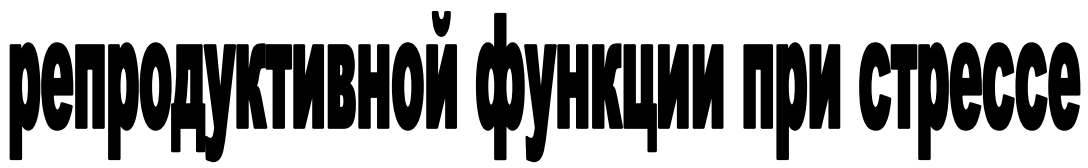

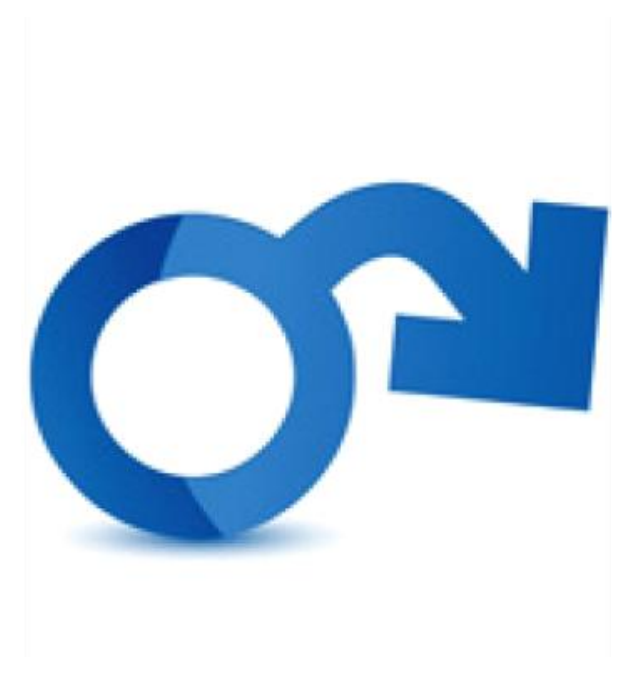

Астрахань-2015 
РОССИЙСКАЯ АКАДЕМИЯ ЕСТЕСТВОЗНАНИЯ ГБОУ ВПО «Астраханский государственный медицинский университет» Минздрава России

\author{
Логинов П.В., Николаев А.А.
}

\title{
СЕЛЕН В КОРРЕКЦИИ \\ РЕПРОДУКТИВНОЙ ФУНКЦИИ ПРИ СТРЕССЕ
}

\author{
Учебно-методическое пособие
}

Рекомендовано УМО РАЕ по классическому университетскому и техническому образованию в качестве учебнометодического пособия для врачей, ординаторов, интернов, обучающихся по специальностям: 06010103 - «Дерматовенерология», 06010147 - «Урология»

(Протокол № 514 от 25 мая 2015 г.)

Астрахань

2015 
УДК: 616.64-084

ББК 28.91

Л69

Логинов, П. В. Селен в коррекции репродуктивной функции при стрессе: Учебно-методическое пособие / П. В. Логинов, А. А. Николаев. - Астрахань : Изд-во «ГБОУ ВПО Астраханский ГМУ», 2015. $80 \mathrm{c}$.

Loginov P.V., Nikolaev A.A. Selenium in reproductive function correction under stress. Astrakhan: Astrakhan State Medical University Publ.; 2015. 80 p. (In Russ.).

В учебно-методическом пособии рассматриваются приёмы коррекции сперматогенеза у животных в условиях хронического воздействия сероводородсодержащего газа и микроволнового излучения низкой интенсивности. Представленные данные базируются на материалах собственных исследований. В пособии рассмотрены также общие вопросы функционирования мужской репродуктивной системы в норме и в условиях однократного и многократного воздействия стрессфакторов.

Рецензенты:

Зам. ген. директора по научной работе ФГБУ «Федеральный научно-клинический центр специализированных видов медицинской помощи и медицинских технологий ФМБА России, доктор медицинских наук Баклаушев В.П.

Доцент кафедры биологической химии с курсом клинической лабораторной диагностики, доктор медицинских наук Кривенцев Ю.А.

Президент Российской академии естествознания, доктор медицинских наук, профессор, академик РАЕ, председатель УМО РАЕ Ледванов М.Ю.

Печатается по решению редакционно-издательского совета Астраханского государственного медицинского университета

ISBN 978-5-4424-0083-0
(C) Логинов П.В., Николаев А.А. (C) Астраханская государственная медицинская академия, 2015 


\section{ОГЛАВЛЕНИЕ}

Предисловие .............................................................................................5

Методические указания ..............................................................7

Глава 1. Функциональное состояние репродуктивной системы в норме и в условиях измененного гомеостаза ....... 10 1.1. Морфофизиологическая характеристика семенников с точки зрения их инкреторной функции ............................. 10

1.2. Сперматогенная функция в норме и в условиях воздействия неблагоприятных факторов ..................................... 15

1.3. Свободнорадикальные окислительные процессы и физиологическая антиоксидантная система семенников ..... 17 1.4. Общая характеристика токсических эффектов сероводородсодержащего газа Астраханского газового месторож-

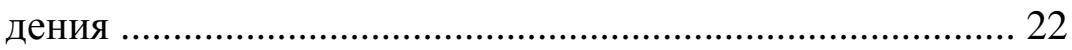

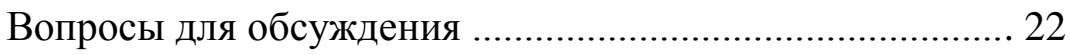

Глава 2. Биохимическая коррекция мужской субфертильности ......................................................................... 25

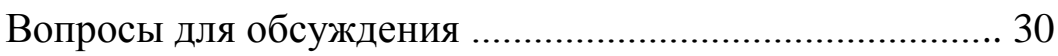

Глава 3. Функциональное состояние репродуктивной системы самцов крыс в условиях острого и хронического стресса 31

3.1. Развитие окислительного стресса в ткани семенников в условиях острого отравления сероводородсодержащим га-

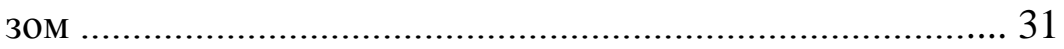

3.2. Роль гипоталамо-гипофизарного комплекса в регуляции функционального состояния семенников в условиях развития окислительного стресса …………….................. 32 3.3. Морфофункциональное состояние семенников в условиях острого сероводородного отравления 39 
3.4. Состояние стероидогенеза и морфофункциональная характеристика семенников в условиях хронической сероводородной интоксикации 40

3.5. Состояние стероидо- и сперматогенеза в условиях многократного воздействия микроволнового излучения низкой интенсивности ............................................................. 44

Вопросы для обсуждения ................................................... 48

Глава 4. Коррекция сперматогенеза с помощью селена у крыс в условиях стресса ……............................................... 49

4.1. Теоретическое обоснование использования селенсодержащих биокомплексов в условиях стресса .................. 49 4.2. Коррекция сперматогенеза в условиях воздействия микроволнового излучения ............................................. 53 4.3. Коррекция сперматогенеза в условиях хронического воздействия природным газом ……………….................. 57

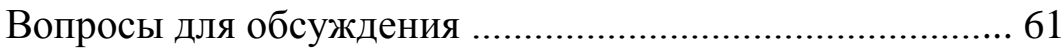

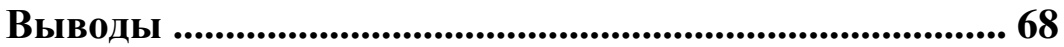

Приложение ..................................................................................... 71

Предметный указатель ........................................................... 72

Список литературы ........................................................... 73 


\section{Стрессом называется неспециифическая реакция организма на любое предъявляе- мое к нему требование.}

Ганс Селье, 1977.

\section{ПРЕДИСЛОВИЕ}

Термин «стресс» стал одним из наиболее модных слов прошедшего столетия. Для большинства неспециалистов стресс - это нечто такое, что имеет отношение к напряженности, беспокойству, дискомфорту, и чего следует избегать. Вместе с тем, стресс - это и научная концепция, проливающая свет на то, как организм высших животных и человека взаимодействует с постоянно меняющимися условиями окружающей среды.

Важным обстоятельством является и тот факт, что избежать стресс невозможно, мы живем в условиях постоянного воздействия различных стресс-факторов, будь то эмоциональных, физических или химических. В этой связи интерес представляет исследование не только механизмов развития окислительного стресса, но и биохимических факторов коррекции метаболических изменений, возникающих в условиях стресса.

Репродуктивная система реагирует на стресс самым решительным образом, вследствие чего происходят выраженные эндокринные, секреторные и морфофункциональные изменения на всех уровнях репродуктивного аппарата. Как следствие, теряется способность к репродукции и копуляции, что и составляет структуру половой функции. 
Мужские половые клетки очень чувствительны к действию свободных радикалов - основных метаболитов в условиях стресса. Поэтому мужское бесплодие играет существенную роль в структуре бесплодия и бесплодных браков. Между тем, исследование биохимических основ бесплодия позволяет подойти ближе к вопросам корректирующих мероприятий в связи с нарушениями мужской репродуктивной системы в условиях стресса. Наряду с использованием таких классических факторов коррекции антирадикального действия, как витамин Е, все более популярными становятся альтернативные биокомплексы на основе селенсодержащих препаратов, имеющих прямое отношение к коррекции нарушений репродуктивной функции. В этой связи пособие предваряется теоретическим обзором воздействия различных неблагоприятных факторов на репродуктивную функцию, а также рассмотрением биохимических основ действия селена на мужской репродуктивный аппарат. Затем приводятся собственные исследования воздействия неблагоприятных факторов среды и способы коррекции возникающих нарушений с помощью селенсодержащего биокомплекса. 


\section{МЕТОДИЧЕСКИЕ УКАЗАНИЯ}

В настоящее время в России, как и во всем мире, наблюдается рост неблагоприятных факторов, существенно ухудшающих экологическое состояние окружающей среды. С 1982 года в Астраханской области ведется промышленное освоение природного газоконденсата с чрезвычайно высоким (иногда до 34 об. \%) содержанием сероводорода. Исследованиям Астраханского природного газа на функциональные системы организма посвящено много работ. В последнее время все больше внимания уделяется исследованию влияния сероводородсодержащего газа Астраханского газоконденсатного месторождения на репродуктивную систему мужчин (Луцкий Д.Л., Николаев А.А., 2000; Ушакова М.В., 2002), поскольку большая часть рабочего контингента на Астраханском газоконденсатном комплексе - мужчины, что определяет особую значимость исследований именно мужской репродуктивной системы. В настоящее время в исследованиях репродуктивной системы заметное предпочтение отдается сперматогенной, а не инкреторной функции, что определяет актуальность исследований влияния экотоксикантов на эндокринный аппарат мужских гонад.

В исследованиях влияния экотоксикантов на репродуктивную систему организма особую роль приобретают функциональные возможности антиоксидантов (АО). При этом чрезвычайно важное значение имеют антиоксидантные свойства витамина Е, определяющие его протекторное действие при развитии окислительного стресса. Вместе с тем, функциональные возможности альтернативных АО 
исследованы недостаточно. Это касается в первую очередь такого биоэлемента, как селен, выступающего в качестве структурообразующего звена ферментативной цепи АOсистемы, а также неотъемлемого компонента в структуре сперматозоидов.

Данное учебно-методическое пособие разработано в соответствии с программой для факультета постдипломного образования (ФПО) по специальностям «Урология», «Дерматология и дерматовенерология» в рамках спецкурса «Молекулярная физиология репродуктивной системы». Данный спецкурс рассчитан на 15 часов аудиторной и самостоятельной работы. В структуру изучаемого курса входят следующие разделы: функционирование мужской репродуктивной системы, молекулярные основы регуляции мужской репродуктивной системы, функционирование мужской репродуктивной системы в условиях воздействия неблагоприятных факторов среды, способы коррекции репродуктивной функции в условиях стресса. По окончании курса обучения проводится зачет по проблемным вопросам. Предполагается чтение 4 двухчасовых лекций в соответствии с изучаемыми разделами, проведение практических занятий (2 часа), консультации (1 час). Самостоятельная работа включает в себя в общей сложности 2 часа подготовки и закрепления полученных знаний. На проведение зачета отводится 2 часа аудиторного времени. Итого 15 часов. Самостоятельная работа включает в себя рассмотрение вопросов и заданий по изучаемым темам. Вопросы и задания приводятся в конце каждой главы пособия. Технической базой при изучении курса являются анатомические 
атласы, а также представленные в данном пособии микрофотографии гистологических срезов тестикулярной ткани. Главы собственных исследований завершаются кратким резюме, отражающим содержательную часть главы. Завершается пособие обобщающим заключением и краткими выводами, после которых следуют практические рекомендации.

Основой для успешного изучения и освоения материала данного учебно-методического пособия являются глубокие знания анатомии, гистологии и физиологии мужского репродуктивного аппарата, знание основ регуляции функционального состояния мужских гонад со стороны гипоталамо-гипофизарного комплекса, а также молекулярных основ функционирования мужской репродуктивной системы. 


\section{Глава 1. Функциональное состояние}

репродуктивной системы в норме и в условиях измененного гомеостаза

1.1. Морфофизиологическая характеристика семенников с точки зрения их инкреторной функции Функциональная характеристика гормонпродуцирующих клеток семенников. Гормонпродуцирующими клетками в семенниках являются клетки Лейдига, образующие интерстициальную ткань, и клетки Сертоли. Клетки Лейдига являются местом синтеза главного андрогена тестостерона. Выделяют 3 типа клеток Лейдига: малые, средние и большие. Малые клетки Лейдига имеют овальную или веретенообразную форму. Ядро располагается в центре, реже эксцентрически. Форма либо округлая (неразвитые клетки), либо в виде тутовой ягоды (инволюционирующие клетки). Жировые вещества у малых клеток Лейдига чаще отсутствуют. В инволюционирующих клетках иногда обнаруживается значительное количество липоидов. Малые клетки Лейдига либо образуют небольшие скопления, либо располагаются в скоплениях средних клеток Лейдига. Ядро средних клеток всегда округлой формы с хорошо выраженным ядрышком. Протоплазма заполнена мелкими капельками жира. Располагаются средние клетки в виде скоплений угловатой формы в промежутках между канальцами. Протоплазма больших клеток Лейдига разграничена на эндо- и эктоплазму, последняя содержит много жира. Большие клетки располагаются изолированно.

Биосинтез тестостерона в семенниках некоторых животных (собак, китов) протекает преимущественно по $\Delta^{5}$ -пути, который включает прегненолон, 17-ОН-прегненолон и андростендиол. У других видов (крысы) может преобладать $\Delta^{4}$-путь, включающий в себя прогестерон, 17-ОНпрогестерон и андростендион. Основным ферментом при 
биосинтезе тестостерона как по $\Delta^{5}$-пути, так и по $\Delta^{4}$-пути считается $\Delta^{5}$-3及-гидроксистероиддегидрогеназа (ГСД).

Основной источник синтеза стероидных гормонов холестерин. В виде липопротеинового комплекса холестерин находится в виде включений в клетках Лейдига. Холестерин может поступать в организм с пищей, либо синтезироваться из ацетил-КоА, являющегося метаболитом в результате распада углеводов, высших жирных кислот ВЖК, некоторых аминокислот и алкоголя.

В андроген-зависимых тканях тестостерон главным образом действует в виде своего 5- $\alpha$-восстановленного продукта - ДГТ. Тестостерон способен подвергаться ароматизации с образованием эстрогенов. Суммарный биологический эффект стероидов определяется соотношением андрогенов и эстрогенов в крови. Андрогены участвуют в развитии и сохранении как первичных, так и вторичных половых признаков. В эмбриогенезе формирование половых органов у мужчин идёт при обязательном участии тестостерона и ДГТ. В зрелом возрасте андрогены влияют на состояние эпителия семенных пузырьков и системы каналов мужского полового аппарата. Под действием андрогенов формируется скелет как независимый вторичный половой признак. От уровня андрогенов зависят также все зависимые вторичные половые признаки.

Главные анаболические эффекты андрогенов - стимуляция роста костей и мышц. Недостаток андрогенов в пуберантном возрасте может стать причиной гигантизма, иногда на почве евнухоидизма. Чрезмерная андрогенизация в препубертатном периоде может приводить к преждевременному заращению эпифизов и низкорослости. Помимо анаболического, андрогены оказывают общеметаболические эффекты, такие как регуляция водно-солевого обмена и распределение подкожного жира. 
Тестостерон оказывает влияние на всех этапах сперматогенеза. Имеются факты стимулирующего действия тестостерона на сперматогонии типа $\mathrm{A}_{0}$ (стволовые половые клетки). В регуляции сперматогенеза тестостерон отвечает за превращение сперматоцитов в сперматиды и их дальнейщую дифференцировку. Доказана зависимость процесса конверсии круглых сперматид в процессе их превращения в сперматозоиды от уровня тестостерона, выделяющегося у основания семенных канальцев. Bremner W.J. и др. (1994) указывают на способность тестостерона оказывать влияние на экспрессию рецепторов андрогенов по паракринному механизму, однако отвергают наличие рецепторов андрогенов на половых клетках, что нисколько не умоляет факта существования этих рецепторов, принимая во внимание возможность стадиоспецифического характера экспрессии рецепторов на половых клетках.

В настоящее время считается, что именно андрогены отвечают за феномен полового влечения не только у самцов, но и у самок (Persky H., Lief H.J., Strauss D., 1978; Имелинский К., 1986; Чичинадзе К., 2004). Имеются данные, что андрогены оказывают влияние на гипоталамические центры преоптической области (Имелинский К.,1986), следствием чего является нарастание полового возбуждения. В условиях же стресса уровень тестостерона снижается. Хронический стресс в препубертатном периоде способен снизить выраженность половой мотивации у взрослых самцов белых крыс (Булыгина В.В., Амстиславская Т.Г., Маслова Л.Н. и др., 2001). Среди возможных механизмов постстрессорного ослабления полового поведения у крыс фигурируют изменения в метаболизме катехоламинов преоптической области (Sato Y., Suzuki N., Horita H. et al., 1996). 


\section{Регуляторные механизмы инкреторной функции}

семенников. Роль гипоталамо-гипофизарного комплекса в регулячии инкреторной функции семенников. Регуляция инкреторной функции гонад осуществляется при посредстве гипофизарных и гипоталамических факторов. На уровне гипофиза ключевую роль в регуляции андрогенопоэза играют гонадотропные гормоны (фолликулостимулирующий гормон ФСГ, лютеинизирующий гормон ЛГ), выделяемые базофильными клетками аденогипофиза, и лютеотропный гормон (пролактин), секретируемый хромофильными клетками аденогипофиза. Концентрация тестостерона в крови определяет уровень секретируемого в кровь лютеинизирующего гормона (лютропина, ЛГ) по механизму отрицательной обратной связи. Сам же ЛГ стимулирует у мужчин секрецию интерстициальными клетками Лейдига андрогенов. ФСГ выделяет вещество, активирующее рецепторы ЛГ на клетках Лейдига. В клетках Сертоли осуществляется ароматизация тестостерона. Образуемый эстроген подавляет секрецию гонадотропных гормонов по механизму обратной связи. Пролактин оказывает ингибирующее влияние на андрогенопоэз в семенниках, а высвобождение гонадотропных гормонов и пролактина контролируется гипоталамическими факторами, которые оказывают либо стимулирующий эффект (либерины), либо ингибирующий эффект (статины). Гонадолиберин (люлиберин, ГнРГ) стимулирует секрецию ЛГ и ФСГ. Секреция люлиберина и гонадотропных гормонов (ГТГ) регулируется механизмом отрицательной обратной связи тестостероном и эстрогенами. Необходимо заметить, что продукция люлиберина и ГТГ зависит также от концентрации рецепторов тестостерона в гипоталамических центрах регуляции секреции гонадотропинов. Чем меньше таких рецепторов, тем ниже уровень тестостерона в крови. В случае экстремального 
блокирования рецепторов андрогенов в соответствующих гипоталамических центрах некоторыми антиандрогенами уровень тестостерона резко повышается, что можно рассматривать как компенсаторный механизм. Необходимо подчеркнуть, что регулярное употребление алкоголя вызывает снижение чувствительности рецепторов андрогенов как в гипоталамусе, так и в аденогипофизе, следствием чего является, однако, снижение концентрации тестостерона в крови. Главные гипоталамические центры регуляции секреции гонадотропинов через посредство возбуждения андрогеновых рецепторов - это прежде всего медиобазальная область, в которой главное место принадлежит аркуатному ядру (АЯ).

Биогенные амины в регулящии инкреторной функиии семенников. Инкубация аденогипофизов в присутствии гипоталамической ткани в среде, обогащённой дофамином, приводит к усилению выделения в эту инкубационную среду ЛГ и ФСГ. Вполне естественно, что дофамин через посредство активации секреции лютропина и ФСГ стимулирует повышение уровня тестостерона в крови. Дофамин в головном мозге легко превращается в НА, который способен также активировать гипоталамо-гипофизарнополовую систему. Gallo R.V. и др. (1971) считают, что в аркуатных ядрах содержатся две популяции нейронов, оказывающих прямо противоположное действие при их возбуждении на секрецию ЛГ. Этим, по-видимому, можно объяснить некоторую противоречивость физиологических эффектов дофамина.

Подкожное введение серотонина приводит к достоверному падению веса семенников и нарушениям в их гистоструктуре. Сосудосуживающий эффект серотонина обусловливает изменение притока гонадотропных гормонов, недостаток которых может быть причиной атрофических 
нарушений в семеннике. Добавление серотонина к инкубируемой ткани медиобазального гипоталамуса вызывает снижение выделения люлиберина в инкубационную среду, что может быть причиной снижения ЛГ и ФСГ в перифрической крови.

\section{2. Сперматогенная функция в норме и в условиях воздействия неблагоприятных факторов}

Процесс сперматогенеза осуществляется в извитых семенных канальцах паренхимы яичка, которые составляют основную массу его. Внутренняя поверхность мембран извитых канальцев выстлана двумя видами клеток - сустентоцитами (клетки Сертоли) и первичными половыми клетками - сперматогониями. Именно здесь недифференцированные семенные клетки сперматогонии размножаются и превращаются в зрелые сперматозоиды (Тиктинский О.Л., Михайличенко В.В., 1999). Клетки Сертоли, выполняя трофическую и фагоцитарную функции в отношении сперматогенных клеток, участвуют в их созревании за счёт секреции ингибина и андрогенсвязывающего протеина, транспортирующего тестостерон и дигидротестостерон (ДГТ) в половые клетки. Ингибин, важнейший регулятор секреции ФСГ аденогипофизом, угнетает продукцию ФСГ (Makanji Y., Walton K.L., Wilce M.C. et al., 2008). Своеобразие клеток Сертоли заключается в том, что они являются мишенями (т. е. содержат специфические рецепторы) как для ФСГ, так и для тестостерона, оказывающих существенное влияние на сперматогенез. Сам процесс развития и созревания сперматозоидов включает в себя 3 этапа (Райцина С.С., 1985; Тиктинский О.Л., Михайличенко В.В., 1999): 1) пролиферация сперматогоний - сперматочитогенез; 2) сперматогенез - мейоз, включающий удвоение ДНК, конъюгацию и кроссинговер хромосом и два клеточ- 
ных деления, приводящих к образованию гаплоидных сперматид; 3) спермиогенез - дифференциация сперматид в сперматозоиды. Окончательное дозревание сперматозоида осуществляется в системе каналов семенника, главным образом в придатке (процессинг сперматозоидов). Способность к оплодотворению яйцеклетки сперматозоиды приобретают в процессе капаситации за счёт акросомальной реакции и увеличения активности жгутика. Сами сперматозоиды выделяют фермент гиалуронидазу, растворяющую слизь шейки матки и, кроме того, создающую условия для внедрения сперматозоида внутрь яйцеклетки.

В последнее время стало известно о регуляторном влиянии некоторых полиаминов на репродуктивную систему млекопитающих (Плосконос М.В., Николаев А.А., Николаев А.А., 2007). Образуемые из путресцина спермин и спермидин, участвующие в процессах биосинтеза белков и нуклеиновых кислот, играют также заметную роль в регуляции репродуктивных процессов.

Сперматогенез можно рассматривать как достоверный показатель качества жизни, ведения здорового образа жизни. На сперматогенез влияют многие факторы. Мужчины с сильной половой конституцией в меньшей степени жалуются на половые расстройства даже на фоне хронического простатита, по сравнению с таковыми со слабой половой конституцией (Беледа Р.В., Михалёв М.А., 2010). К нарушению фертильности могут приводить не только генетические, но и гормональные, инфекционные, иммунологические, сосудистые, неврологические заболевания, экологические факторы.

С годами сперматогенная функция падает. Функциональные обязанности сустентоцитов, участвующих в развитии и созревании половых клеток, с годами упраздняются в связи с их численным сокращением, что вполне 
естественно. Сами сустентоциты видоизменяются: хроматин в ядре приобретает компактный характер, цитоплазматические структуры редуцируются, процесс обновления мембранных и вакуолярных компонентов цитоплазмы тормозится, имеет место накопление инертных компонентов в виде липофусцина и включений липидов.

\section{3. Свободнорадикальные окислительные процессы и физиологическая антиоксидантная система семенников}

Перекисное окисление липидов в условиях стресса и развития патологических состояний. При стрессе нарушаются различные физиологические функции: щитовидной железы, кровообращения, сердца, иммунитета, психические, а также половые. Стресс индуцирует интенсификацию свободнорадикальных окислительных процессов, что обусловливает нарушение целостности биологической мембраны за счет одновременного усиления липолиза.

Физическая нагрузка, температурное воздействие, рентгеновское облучение, бессонница и другие факторы могут оказать стрессирующее влияние на живой организм. Физическая нагрузка, особенно длительная, вызывает усиление процессов ПОЛ в ткани семенников (Овсянникова Т.Н., Лемешко В.В., 1991). В условиях бессонницы также наблюдается усиление липолиза, что можно рассматривать как фактор, способствующий развитию атеросклероза. Повышенная температура как после однократного воздействия, так и после многократного воздействия вызывает повышение интенсификации СРО (Овсянникова Т.Н., Лемешко В.В., 1991). В условиях же хронического холодового стресса наблюдается достоверное снижение гидроперекисей и малонового диальдегида в тканях животных. Подобный факт обусловлен феноменом закаливания, который 
выражается в активации антиоксидантной защиты тканей. Радиационное облучение вызывает снижение уровня витамина Е в семенниках, что свидетельствует о том, что в семенниках создаются условия, поддерживающие выработку свободных радикалов (Евдокимов В.В., Коденцова В.М., Курило Л.Ф. и др., 1999).

Интенсификации ПОЛ способствуют химические стресс-индуцирующие факторы. Ряд фармакологических препаратов и промышленных отходов способны создать в живой клетке состояние напряжения. Природный газ Астраханского газоконденсатного месторождения

(АГКМ) вызывает усиление процессов СРО в крови человека и животных, в тканях головного мозга и печени (Мажитова M.В., 2000; Пюрведжалова Э.Б., 2004).

При голодании обмен веществ переключается с углеводного на жировой. В связи с этим создаются условия для процесса перекисного окисления липидов. В условиях недостатка витамина Е в семенниках возникают дегенеративные изменения, связанные с усилением процессов пероксидации.

\section{Физиологическая антиоксидантная система.}

Торможение аутоокисления в клетке осуществляется антиоксидантной системой (АОС). Группа антиперекисных ферментов (глутатионпероксидазы, супероксиддисмутазы, каталазы) участвует в регуляции метаболизма АКМ. К неферментативной АОС относят цепь антиоксидантов, участвующих в гашении свободных радикалов. Цепь антиоксидантов включает в себя $\alpha$-токоферол, аскорбиновую кислоту, глутатион (или эрготионеин). $\alpha$-Токоферол является главным в этой цепи антирадикальным антиоксидантом. Окисленный токоферол регенерируется аскорбиновой кислотой, а окисленные формы аскорбата, в свою очередь, восстанавливаются глутатионом (или эрготионеином), по- 
лучающим атомы водорода от НАДФ или НАД (пиридиннуклеотидов).

Пептиды, содержащие в своем составе аминокислоту гистидин, обладают также антиокислительными свойствами. Известно, что аминокислота аргинин является источником генерации оксида азота NO, имеющего неспаренный электрон, а потому проявляющего антиоксидантные свойства (Милютина Н.П., Ананян А.А., Щюгалей В.С., 1990). Известно участие селена в реакциях антиоксидантной защиты. Особенно указанный эффект проявляется в условиях сочетания витамина Е и селена.

Витамин $\mathrm{E}(\alpha-$-токоферол) является ключевым звеном неферментативной антиоксидантной системы. Ненасыщенные жирные кислоты могут образовывать с $\alpha$ токоферолом $(\alpha-T \Phi)$ комплексы за счет взаимодействий 2 типов: 1) полярного взаимодействия ОН-группы хроманового ядра $\alpha$-ТФ с С-О-группой жирных кислот (ЖК); 2) неполярного взаимодействия ацильных цепей ЖК с метильными группами хроманового ядра $\alpha-$ ТФ, в частности, с фитильной цепью (Скрыпин В.И., Ерин А.Н., Каган В.Е. и др., 1986). Фитильная, или боковая длинная углеводородная цепь, обусловливает лучшее внедрение антиоксиданта (AО) в липидный бислой. Это одновременно способствует стабилизации этого бислоя. Взаимодействие экзогенно добавляемого $\alpha$-токоферола с липосомами приводит к включению его прежде всего в доступный наружный монослой. При включении $\alpha-T Ф$ в оба монослоя не происходит перемещение его между наружным и внутренним монослоями (Тюрин В.А., Каган В.Е., Сербинова Е.А. и др., 1986). При Е-дефицитном состоянии повышается ПОЛ, увеличивается текучесть биомембраны, и в результате нарушается функциональное состояние мембраны. 
Антиоксидантный эффект $\alpha$-ТФ (НТФ) обусловлен его способностью гасить свободные радикалы $\mathrm{RO}_{2}{ }^{*}$ (или $\mathrm{LO}_{2}{ }^{\circ}$ ) (Дмитриев Л.Ф., Верховский М.И., 1990):

$$
\begin{aligned}
& \mathrm{LO}_{2}{ }^{\circ}+H T \Phi \rightarrow L O O H+T \Phi^{\circ} \\
& \mathrm{LO}_{2}{ }^{\circ}+T \Phi^{\circ} \rightarrow L O O-T \Phi
\end{aligned}
$$

Образуемые гидроперекиси (1) распадаются за счет глутатионпероксидазы. Однако этот механизм не является исчерпывающим. $\alpha$-ТФ (НТФ) в водной среде окисляется по двухэлектронному механизму (Marcus M.F., Hawley M.D., 1970):

$$
\mathrm{HT} \Phi \rightleftarrows \mathrm{T}^{+}+\mathrm{H}^{+}+2 \mathrm{e}^{-}
$$

В связи с этим механизм взаимодействия НТФ со свободными радикалами можно представить следующим образом:

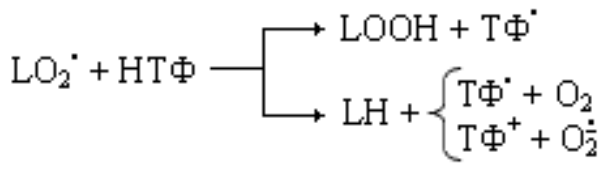

Таким образом, из последней схемы видно, что витамин Е участвует в регенерации уже окисленной жирной кислоты. Указанный факт согласуется с данными, согласно которым регенерация молекул липидов, подвергнутых окислению, осуществляется $\alpha$-токоферолом в присутствии глутатион- $\mathrm{LO}_{2}$-редуктазы и глутатиона (Дмитриев Л.Ф., Иванова М.В., Лебедев А.В., 1995).

$$
\begin{gathered}
\mathrm{LO}_{2}{ }^{\circ}+\mathrm{e}^{-} \stackrel{\text { pedymasa }}{\longrightarrow} \mathrm{L}^{\cdot}+\mathrm{O}_{\overline{2}} \\
\mathrm{~L}^{\circ}+\mathrm{HT} \Phi \longrightarrow \mathrm{LH}+\mathrm{T}^{\circ}{ }^{\circ}
\end{gathered}
$$

Таким образом, $\alpha$-токоферол, исходя из приведенных выше схем, является антиоксидантом антирадикального действия. Антирадикальные свойства $\alpha$-токоферола обусловлены, с одной стороны, подвижностью протона в его молекуле, а с другой - устойчивостью феноксильного радикала, образуемого в ходе отдачи атома водорода. 
Физиологические дозы $\alpha$-токоферола вызывают антиоксидантный эффект, а сверхфизиологические дозы «способствуют перенапряжению антиоксидантной системы биомембран и интенсификации свободнорадикальных процессов» (Теплый Д.Л., 1984, 1990).

В целом же витамин Е ( $\alpha$-токоферол) известен нам больше как антиоксидант, нежели как прооксидант. В условиях недостатка витамина Е возрастает уровень генерации свободных радикалов, которые приводят к нарушению барьерной функции биологических мембран, в частности, мембран нервных клеток, мембран эритроцитов, мембран саркоплазматического ретикулума. Следствием нарушения функционального состояния биомембран является нарушение внутриклеточных процессов жизнедеятельности.

Антиоксидантная система семенников. Сперматогенный эпителий относится к быстро пролиферирующим тканям, весьма чувствительным к повреждающему действию продуктов СРО. Изучение уровня основных компонентов антирадикальной цепи выявило высокое содержание аскорбата, превышающее величины, определяемые в других тканях (Созашвили Ш.Т., 1970), достаточно высокое содержание тиоловых соединений, весьма высокую активность ферментов утилизации активных форм кислорода (Бобырев В.Н., Почерняева В.Ф., Стародубцев С.Г. и др., 1994). Таким образом, для семенников в системе АОС особое значение имеют токоферол, аскорбиновая кислота и эрготионеин (тиоловое соединение), а также группа антиокислительных ферментов.

В условиях недостатка витамина Е репродуктивная система страдает в первую очередь: наблюдается снижение сперматогенеза, потеря подвижности сперматозоидов, отложение липофусцина. Введение витамина Е животным приводит к снижению генерации свободных радикалов, что 
положительно сказывается на копулятивном поведении и качестве семенной жидкости.

Семенники в условиях гипервитаминоза Е претерпевают дегенеративные изменения. Изолированный Савитаминоз при достаточном поступлении токоферола не сопровождается резким усилением СРО, так как токоферол в этом отношении частично заменяет аскорбат. Однако при длительном лишении такого важного компонента АОC, как аскорбиновая кислота, происходит нарушение клеточного деления, что в итоге приводит к дегенеративным изменениям ткани. Эрготионеин оказывает прямой протекторный эффект в отношении спермиев.

\section{4. Общая характеристика токсических эффектов сероводородсодержащего газа Астраханского га- зового месторождения}

Сероводородсодержащий природный газ (СВСГ) Астраханского газоконденсатного месторождения (АГКМ) относится к группе экзогенных химических патогенных факторов. Сочетание нескольких канцерогенных веществ взаимоусиливает их токсические эффекты, как, например, в случае СВСГ АГКМ, состоящего из углеводородов, сероводорода, диоксида углерода и других компонентов. Химические канцерогены, к которым можно отнести и сероводородсодержащий газ, интенсифицируют процесс старения, угнетают функцию гипоталамуса, который в процессе старения становится менее надежной системой, что способствует развитию патологий. Даже такой канцероген как табачный дым в условиях его постоянной ингаляции приводит к сдвигам в гипоталамно-гипофизарной области и структурным изменениям в семенниках. 
Вредные последствия $H_{2} S$ сводятся к минимуму благодаря его превращению в менее токсичные соединения, в частности, в сульфат, который выводится с мочой.

Под действием СВСГ АГКМ увеличивается уровень СРО в больших полушариях и гипоталамусе белых крыс. Высокие дозы газа АГКМ приводят к структурным изменениям супрахиазматического ядра (СХЯ), имеющего отношение к регуляции полового поведения и циркадных ритмов. Изучение влияния газа с концентрацией по $\mathrm{H}_{2} \mathrm{~S}$ $300 \mathrm{мг} / \mathrm{M}^{3}$ позволяет констатировать выраженный эмбриотоксический эффект на морфологические характеристики СХЯ, особенно на ранних стадиях беременности крыс.

В условиях острой и хронической сероводородной интоксикации напряженно функционируют клетки аденогипофиза, вырабатывающие ТТГ, СТГ и АКТГ. Химический стресс, вызванный промышленными токсикантами, ингибирует секрецию ЛГ и ФСГ.

Шевлюк Н.Н. (1993) провел морфологическое исследование интерстициальных эндокриноцитов семенников сусликов из популяции, обитающей в санитарной зоне Оренбургского газоперерабатывающего завода. Результаты эксперимента показали наличие структурно-функциональных изменений. Наблюдается повышение числа клеток Лейдига отросчатой формы, имеющих неправильной формы ядро. В цитоплазме отмечено расширение везикул и канальцев эндоплазматической сети.

\section{Вопросы для обсуждения}

1. Перечислите основные виды клеток Лейдига.

2. Основные метаболические эффекты андрогенов.

3. В чем главное различие в химической структуре тестостерона и эстрадиола? 
4. Какую роль выполняют биогенные амины в регуляции репродуктивных процессов?

5. Механизмы прямой и обратной связи в регуляции инкреторной функции семенников.

6. Перечислите этапы развития и созревания мужских половых клеток.

7. Что такое сперматогенез и где именно он происходит?

8. Каковы основные факторы регуляции сперматогенеза?

9. Как осуществляется взаимодействие инкреторной и экскреторной функций семенников?

10. Что такое спермин и спермидин? Каково их значение в сперматогенезе?

11. Каков механизм пероксидного окисления липидов?

12. Каково значение процесса пероксидного окисления липидов в норме?

13. Роль перекисного окисления липидов в развитии патологий.

14. Физиологическая антиоксидантная система.

15. Неферментативное звено антиоксидантной системы.

16. Жирорастворимые и водорастворимые антиоксиданты.

17. Антиоксидантные и прооксидантные свойства витамитна Е.

18. Физиологическая антиоксидантная система семенников.

19. Токсические эффекты Астраханского природного газа.

20. Последствия токсического воздействия сероводородсодержащего газа на организм. 


\section{Глава 2. Биохимическая коррекция мужской субфертильности}

В последнее время интерес ученых всего мира вызывают состояния, связанные с избытком, недостатком или дисбалансом микроэлементов в организме человека. В этой связи огромный интерес представляют такие элементы, как селен и цинк (Полунин А.И., Луцкий Д.Л., Мирошников В.М., Николаев А.А., 2002). О роли цинка в регуляции репродуктивных процессов накоплено достаточно сведений (см. Приложение). Одним из наиболее интересных и малоизученных элементов является селен, который в настоящее время относят к группе эссенциальных микроэлементов.

Роль селена в патологии человека была установлена после описания селенодефицитной кардиомиопатии в Китае (болезнь Кешана), а также объяснения клинических явлений недостаточности селена при полном парентеральном питании. Характеристика и механизм развития селенодефицитных заболеваний установлены только в последние годы, хотя их многие нюансы до сих пор остаются неясными и спорными (Loembeck I., Ebert K.H., Kasperek K. et al., 1984).

Всасывание селена может осуществляться через пищеварительный тракт, кожу и лёгкие. Усвоение растворимых форм селена в пищеварительном тракте происходит на 80-100\%. Установлено, что органические соединения селена усваиваются лучше, чем неорганические. Наиболее интенсивно всасывание селена происходит в двенадцатиперстной и в несколько меньшей степени в тощей и подвздошной кишках. В желудке этот микроэлемент практически не усваивается. Транспорт и депонирование селена осуществляется, по-видимому, особыми белками, содержащими селеноцистеин, и названными соответственно селенопротеином-Р плазмы и селенопротеином-Р 1 почек и 
печени (Motsenbocker M.A., Tappel A.L., 1984). Схематично транспорт и накопление соединений селена можно отразить следующей схемой:

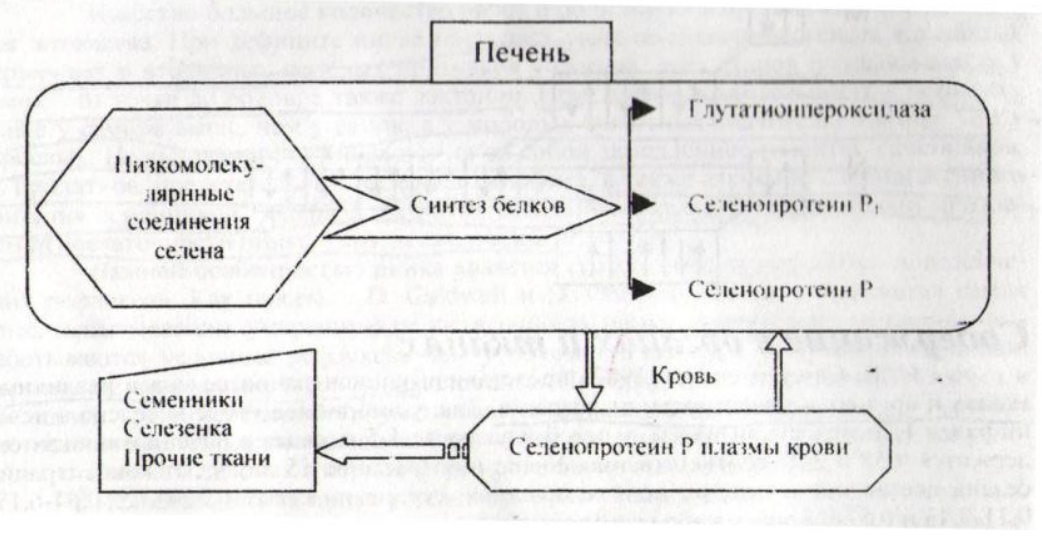

Селен обладает большим сходством с серой. Их атомы имеют близкую конфигурацию наружных электронных оболочек, почти одинаковые размеры и сходные энергетические связи, ионизационные потенциалы и сродство к электронам. В то же время, в живых системах эти два элемента ведут себя зачастую по-разному. В частности, в организме животных соединения селена подвергаются обычно восстановлению, а серы - окислению. Селеноводород является более сильной кислотой, сероводород, и диссоциирован в большей степени, чем последний.

Из организма селен элиминируется тремя основными путями - через почки, кишечник и выдыхаемый воздух. Однако в большинстве экспериментов и клинических наблюдений установлено, что в физиологических условиях гомеостаз селена регулируется в основном его экскрецией с мочой в течение 24 часов после введения в организм (Скальный А.В., Орджоникидзе 3.Г., Громова О.А., 2000). 
С годами концентрация селена в органах и тканях уменьшается. Низкий уровень селена в волосах и в крови, а также невысокая активность глутатионпероксидазы у детей встречается не только при болезни Кешана, но и при полном парентеральном питании, при содержании детей с фенилкетонурией и «болезнью запаха кленового сиропа» на полусинтетической диете. Во всех этих случаях введение препаратов селена в организм ведет к нормализации биохимических параметров и нередко сопровождается положительным терапевтическим эффектом (Скальный А.В., 1999).

У всех изученных видов экспериментальных животных дефицит селена вызывает нарушение репродуктивной функции. Крысы при дефиците селена не утрачивают способность приносить потомство, но уже первое поколение лишено этой способности. У одной части животных сперматозоиды теряют подвижность, их хвост отрывается от головки. У другой части животных сперматозоиды полностью исчезают. Самки приносят всего 1-2 нежизнеспособных детёныша. У кур и индюков дефицит селена приводит к снижению яйценоскости и выводимости цыплят (Полунин А.И., Луцкий Д.Л., Мирошников В.М., Николаев А.А., 2002). Во всех случаях нарушений воспроизводительной функции введение животным одного гонадотропного витамина Е не дает положительного эффекта. В ряде селенодефицитных биогеохимических провинций Шотландии и Калифорнии при добавлении к корму мелкому и крупному рогатому скоту селена и витамина Е было отмечено улучшение репродуктивной функции животных (Underwood E.G., 1977). Взаимосвязь между селеном и витамином Е объясняется их воздействием на разные этапы образования органических перекисей. Токоферолы служат антиоксидантами по отношению к ненасыщенным липидам плазма- 
тической мембраны, предохраняя их от разрушительного действия свободных радикалов. Селенсодержащая глутатионпероксидаза разрушает как перекись водорода, так и перекиси липидов. Глутатионпероксидаза - первый селенсодержащий фермент, найденный в организме млекопитающих. Он предохраняет клетки от токсического действия перекисных радикалов. Фермент не обладает строгой специфичностью по отношению к перекисям и нуждается в качестве кофактора в глутатионе, который в ходе ферментативной реакции подвергается окислению:

$$
\begin{aligned}
& \mathrm{H}_{2} \mathrm{O}_{2}+2 \mathrm{GSH} \rightarrow 2 \mathrm{H}_{2} \mathrm{O}+\mathrm{GSSG} \\
& \mathrm{ROOH}+2 \mathrm{GSH} \rightarrow \mathrm{ROH}+\mathrm{H}_{2} \mathrm{O}+\mathrm{GSSG}
\end{aligned}
$$

Селен физиологически активен, а биологическое действие теллура и полония не выявлено. В живых организмах селен, как и сера, входит в состав биосубстратов в степени окисления -2 . Вследствие близости химических свойств этих элементов они могут замещать друг друга в соединениях. При этом селен может выступать как синергистом, так и антагонистом серы, о чем свидетельствует биологическая активность селенсодержащих соединений.

При поступлении в организм селен прежде всего накапливается в ногтях и волосах. Их основу составляют серосодержащие аминокислоты цистеин и метионин. Селен замещает атомы серы в этих аминокислотах, превращая их в селеноцистеин и селенометионин. Эти необычные кислоты также входят в состав активных центров следующих ферментов: глутатионпероксидазы (ГП), глутатионредуктазы и формиатдегидрогеназы, обеспечивая их высокую ферментативную активность. Хорошо известна способность селена предохранять организм от отравления ртутью и кадмием. Причем связывание катионов этих токсичных металлов происходит не селенсодержащими группами метаболитов, а другими активными центрами, которые мало 
влияют на биологическую активность метаболитов. Интересным является также факт взаимосвязи между низкой смертностью от рака и высоким содержанием селена в пище. В то же время замещение группы SH на группу $\mathrm{SeH}$ в ряде ферментов приводит к снижению их дегидрогеназной активности и ингибированию клеточного дыхания.

Соединения, содержащие $\mathrm{Se}^{+4}$, - селениты - более токсичны, чем цианиды. Это, вероятно, вызвано их окислительными свойствами, из-за которых происходит превращение тиолсодержащих белков (Prot SH) в белки, содержащие группы -S-Se-S-:

$\mathrm{H}_{2} \mathrm{SeO}_{3}+4$ Prot-SH $\rightarrow$ Prot-S-Se-S-Prot + Prot-S-S-Prot $+3 \mathrm{H}_{2} \mathrm{O}$ Наличие такой группы может привести к изменению третичной структуры белков и нарушеню их биологической функции (Слесарев В.И., 2007).

Интересно, что дефицит селена (например, при содержании грызунов на полусинтетическом амнокислотном рационе) неизбежно приводит к резкому снижению цинка в поджелудочной железе, в паренхиме почек и в клетках сперматогенного эпителия. Если роль селена как протектора сперматогенеза у животных определена достаточно четко (Авцын А.П., Жаворонков А.А., Риш М.А. и др., 1991), то его влияние на фертильность мужчин до сих пор изучено недостаточно полно. Одни авторы утверждают, что при недостатке селена возрастает вероятность мужского бесплодия, поскольку этот микроэлемент обладает выраженным защитным действием по отношению к сперматозоидам, обеспечивая их подвижность. Существуют данные, как подтверждающие положительный эффект от применения селена у субфертильных мужчин, так и отвергающие подобное действие (Луцкий Д.Л., 2000).

Наиболее известным проявлением недостаточности селена у животных является алиментарная мышечная дис- 
трофия (беломышечная болезнь). В последние годы дефицит селена рассматривают как возможный этиологический фактор при некоторых сердечно-сосудистых заболеваниях.

Экспериментальные исследования привлекли к еще одной форме селенодефицита, протекающего на фоне недостаточности витамина $\mathrm{E}$ - эозинофильному энтериту человека, домашних и лабораторных животных, возникающему, очевидно, в связи с избыточным образованием продуктов окисления.

В литературе имеются лишь немногочисленные данные об отравлении селеном человека. Наиболее типичными симптомами селенового токсикоза являются поражения ногтей и волос. Избыток селена в среде неблагоприятно влияет на процессы оссификации и на состояние зубов.

\section{Вопросы для обсуждения}

1. Электронное строение атома селена.

2. Взаимосвязь селена и цинка.

3. Содержание селена в органах и тканях.

4. Поступление селена в организм.

5. Транспорт селена в организме.

6. Элиминация селена.

7. Физиологическая роль селена.

8. Молекулярные основы патологии при недостатке или избытке селена.

9. Взаимосвязь между обменом серы и селена.

10. Токсичность соединений селена.

11. Антиканцерогенные свойства селена.

12. Селенсодержащие ферменты.

13. Синергизм селена и витамина Е.

14. Роль селена в регуляции репродуктивных процессов. 


\section{Глава 3. Функциональное состояние репро-}

\section{дуктивной системы самцов белых крыс в}

\section{условиях острого и хронического стресса}

А. Функциональное состояние репродуктивной системы самцов белых крыс в условиях острого сероводородного отравления

3.1. Развитие окислительного стресса в ткани семенников в условиях острого отравления сероводородсодержащим газом

Для оценки уровня СРО и выраженности в связи с этим липолитических процессов в крови проводилось измерение степени перекисной резистентности эритроцитов (ПРЭ). Для оценки стресс-реакции проводилась эозинопеническая проба, которая заключалась в подсчете числа эозинофильных гранулоцитов в 1 мм $^{3}$ крови (Ронин В.С., Старобинец Г.М., 1989). Эозинопеническая проба и увеличение относительной массы надпочечников указали на развитие стресса у самцов белых крыс в условиях однократного воздействия СВСГ АГКМ. Усиление процессов СРО в плазме крови коррелирует с возрастанием перекисного гемолиза эритроцитов в условиях сероводородной интоксикации. Перекисное окисление липидов в гомогенатах семенников и гипоталамуса определяли по методу И.Д. Стальной и Т.Г. Гаришвили (1977) в модификации Е.А. Строева и В.Г. Макаровой (1986), основанном на реагировании одного из конечных продуктов - малонового диальдегида - с тиобарбитуровой кислотой с образованием окрашенного триметинового комплекса с максимумом поглощения в области 532 нм. В условиях сероводородной интоксикации наблюдалось достоверное повышение исходного уровня МДА, одного из конечных продуктов ПОЛ, в сравнении с контролем (P $<0,01)$, что свидетельствует об 
усилении процессов СРО в ткани семенников. Введение 2 мг $\alpha$-токоферола $(\alpha-\mathrm{T} Ф)$ животным практически не сказалось на уровне исходного МДА.

Окислительно-восстановительная активность ткани семенников под действием газа достоверно увеличилась (Р $<0,05)$. Двухнедельное введение $\alpha$-ТФ дозе 2 мг на 100 г массы тела животного не вызвало существенных изменений этого показателя. Вместе с тем, предварительное введение $\alpha$-ТФ перед воздействием сероводородсодержащего газа вызвало снижение окислительно-восстановительного потенциала (ОВП) на 22,5\% в сравнении с группой животных, подвергнутых воздействию СВСГ АГКМ $(\mathrm{P}<0,001)$.

\section{2.Роль гипоталамо-гипофизарного комплекса в ре-} гуляции функционального состояния семенников в условиях развития окислительного стресса

3.2.1. Изменение инкреторной функции гипофизарногонадного комплекса под действием $\alpha$ токоферола, сероводородного отравления и их сочетания.

Функциональное состояние гипофизарносеменникового комплекса рассматривали с учётом анализа двух составляющих: 1) изменение секреции тестостерона и ЛГ; 2) изменение относительной массы гипофиза и семенников.

Изменение секреции тестостерона и ЛГ. Под действием СВСГ АГКМ наблюдалось снижение уровня тестостерона в плазме крови самцов белых крыс на 85 \%, в сравнении с контролем $(\mathrm{P}<0,001)$. Вводимый в течение двух недель витамин Е в дозе 2 мг вызывает некоторое повышение уровня тестостерона с 1,415 нг/мл до 1,702 нг/мл в плазме крови, а уровень ЛГ в тех же условиях достоверно повышался более чем на $115 \%($ Р $<0,001)$ (рис. 1). 

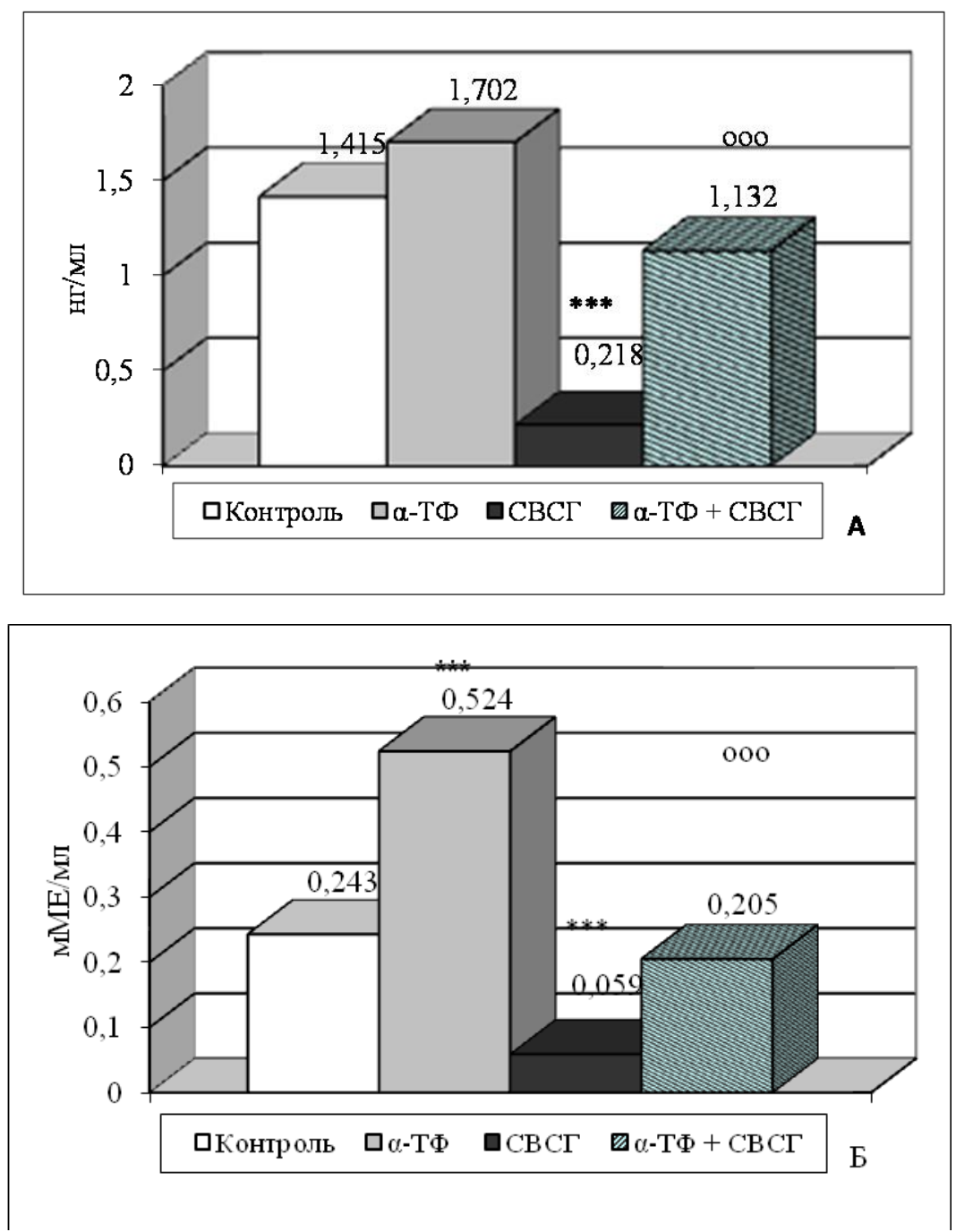

Рис. 1. Изменение уровня тестостерона (а) и лютеинизирующего гормона (б) в плазме крови под действием СВСГ АГКМ, $\alpha$-токоферола и их сочетания. *** - $\mathrm{P}<0,001$ - в сравнении с контролем; ооо - $\mathrm{P}<0,001$ - в сравнении с группой животных, подвергнутых воздействию СВСГ АГКМ 
Введение $\alpha$-ТФ вызывало повышение уровня тестостерона в ответ на усиление секреции ЛГ с коэффициентом положительной корреляции $(\mathrm{r}=+0,948, \mathrm{P}<0,001)$. Гипофиз, наряду с гонадами, надпочечниками и жировой тканью отличается от других органов высоким содержанием токоферола, что может служить косвенным доказательством его роли в синтезе и выделении тропных гормонов.

Предварительное введение $\alpha$-токоферола в дозе 2 мг в течение двух недель с последующим воздействием СВСГ, вызывало стабилизацию уровня тестостерона и ЛГ в плазме, что еще раз подтверждает возможное участие $\alpha$ токоферола в регуляции синтеза половых гормонов, которая в определенной степени связана с антиоксидантной функцией $\alpha$-токоферола в условиях развития окислительного стресса. Проведенное исследование позволяет считать, что изменение синтеза тестостерона вызвано воздействием сероводородсодержащего газа, определяющего нарушение функциональной взаимосвязи инкреторной функции семенников и гонадотропной функции гипофиза.

Изменение относительных масс гипофиза и семенников. Изменения гонадотропной функции гипофиза и функционального состояния семенников под действием $\alpha$ токоферола и сероводородсодержащего газа коррелируют с изменением их относительных масс (табл. 1).

Таблица 1

Изменение относительной массы гипофиза и семенников под действием СВСГ АГКМ, $\alpha$-токоферола и их сочетания

\begin{tabular}{|c|c|c|c|}
\hline Условия опыта & $\mathrm{n}$ & $\begin{array}{c}\text { Относительная мас- } \\
\text { са гипофиза, мг/г }\end{array}$ & $\begin{array}{c}\text { Относительная масса } \\
\text { семенников, \% }\end{array}$ \\
\hline 1) Контроль & 6 & $0,026 \pm 0,0019$ & $0,79 \pm 0,033$ \\
\hline 2) $\alpha-T \Phi$ & 6 & $\begin{array}{c}* * \\
0,032 \pm 0,0015\end{array}$ & $\begin{array}{c}* * \\
0,92 \pm 0,044\end{array}$ \\
\hline 3) $\mathrm{CBCГ}$ & 6 & $0,027 \pm 0,0018$ & $0,82 \pm 0,015$ \\
\hline 4) $\alpha-Т \Phi+C В С Г$ & 6 & $0,024 \pm 0,0020$ & $* 0,96 \pm 0,058$ \\
\hline
\end{tabular}


Из таблицы 1 видно, что введение животным $\alpha$ токоферола вызывает повышение относительной массы гипофиза, что может свидетельствовать об усилении функциональной активности гипофиза под влиянием витамина Е. Под действием $\alpha$-токоферола масса семенников увеличилась на $16,5 \%(\mathrm{P}<0,05)$. Введение $\alpha$-токоферола с последующим воздействием СВСГ приводило к еще большему увеличению относительной массы семенников (на $21,5 \%)$, в сравнеии с контролем $(\mathrm{P}<0,05)$, что говорит о возможном вкладе сероводородсодержащего газа в развитие отечных явлений.

Из всего вышеприведённого следует, что $\alpha$ токоферол в небольших дозах оказывает благоприятное воздействие на функциональное состояние гонад. Вместе с тем инкреторная функция семенников находится под жёстким контролем аденогипофиза, который, в свою очередь, испытывает влияние со стороны медиобазального гипоталамуса, в пределах которого сосредоточены центры регуляции репродуктивного поведения.

3.2.2. Изменение функционального состояния гипоталамуса по уровню СРО в условиях сероводородной интоксикации и корректирующие эфректы витамина $E$.

В условиях проводимого нами эксперимента выявлено, что под действием СВСГ наблюдалось повышение количества конечного продукта липопероксидации - малонового диальдегида (МДА) в ткани медиобазального гипоталамуса почти в 2 раза в сравнении с контролем $(\mathrm{P}<0,05)$ (табл. 2). Предварительное введение $\alpha$-токоферола с последующей интоксикацией СВСГ стабилизировало уровень МДА в ткани гипоталамуса. 
Таблица 2

Изменение уровня МДА в ткани гипоталамуса

под действием СВСГ АГКМ и $\alpha$-токоферола

\begin{tabular}{|l|c|c|}
\hline $\begin{array}{c}\text { Условия } \\
\text { опыта }\end{array}$ & $\mathbf{n}$ & МДА, нмоль \\
\hline 1) Контроль & 5 & $3,03 \pm 0,391$ \\
\hline 2) $\alpha$-ТФ & 5 & $3,40 \pm 0,295$ \\
\hline 3) СВСГ & 5 & $*$ \\
& $5,90 \pm 0,870$ \\
\hline $\begin{array}{l}4) \alpha-Т Ф+ \\
\text { СВСГ }\end{array}$ & 5 & $\begin{array}{c}0 \\
3,67 \pm 0,345\end{array}$ \\
\hline
\end{tabular}

* - $\mathrm{P}<0,05$ - в сравнении с контролем; 0 - $\mathrm{P}<0,05$ - в сравнении с группой животных, подвергнутых воздействию СВСГ АГКМ

Угнетение инкреторной функции семенников под действием СВСГ АГКМ является, очевидно, следствием угнетения функциональной активности гипоталамогипофизарного комплекса, что находится в соответствии с исследованиями Б.В. Алешина и Л.А. Бондаренко (1982), которые связывают угнетение тестикулярного андрогенопоэза в условиях стресса с усиленной выработкой пролактина и блокадой ЛГ аденогипофизом в кровяное русло. Блокада выброса ЛГ, в свою очередь, обусловлена, с одной стороны, усилением процессов СРО в гипоталамической ткани, а с другой - повышенной секрецией серотонина медиобазального гипоталамуса, что в целом тормозит секрецию люлиберина в область срединного возвышения. Таким образом, угнетение инкреторной и связанной с ней экскреторной функции семенников в условиях развития оксидативного стресса обусловлено, очевидно, прежде всего нарушением функционального состояния гипоталамуса, если принять во внимание концепцию стресса К.В. Судакова (1997), хотя не исключено прямое воздействие токсических эффектов сероводородсодержащего газа на эндокриноциты семенников. 
Метаболизм сероводорода обстоятельно рассмотрен в работах Р.И. Асфандиярова (1995). Участие сероводорода в развитии окислительного стресса можно схематически выразить следующей схемой.

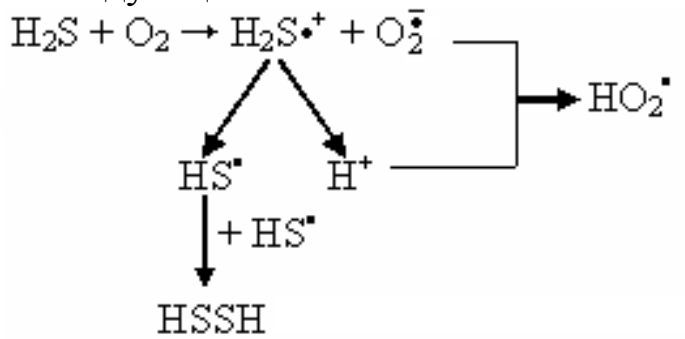

(персульфид водорода; «д исульфид))

Допустим и другой альтернативный механизм окисления сероводорода:

$$
\begin{gathered}
\mathrm{H}_{2} \mathrm{~S} \rightleftarrows \mathrm{HS}^{-}+\mathrm{H}^{+} \longrightarrow \\
\mathrm{HS}^{-}+\mathrm{O}_{2} \rightarrow \underset{\mathrm{HS}^{*}}{ }+\mathrm{O}_{2}^{-}-\mathrm{HO}_{2}^{-} \\
\downarrow+\mathrm{HS}^{*}
\end{gathered}
$$

HSSH

(персульфид водорода; «д исульфид))

Далее дисульфид по аналогии подвергается дальнейшему окислению:

$$
\mathrm{HSSH}+\mathrm{O}_{2} \rightarrow \mathrm{HSS}^{\circ}+\mathrm{HO}_{2}^{\circ}
$$

Радикал сульфидной серы весьма активен в отношении других радикалов, таких как $\mathrm{O}_{2}$ или $\mathrm{HO}_{2}$, что открывает новый каскад химических преобразований:

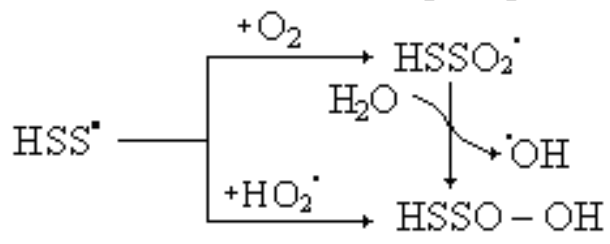


Как любая гидроперекись, HSSO - OH легко распадается. При этом продукты распада, очевидно, претерпевают изменения, подвергаясь перегруппировке:

$$
\begin{gathered}
\mathrm{HSSO}-\mathrm{OH} \rightarrow \mathrm{HSSO}^{\circ}+{ }^{\circ} \mathrm{OH} \\
\mathrm{HSSO}^{\circ} \leftrightarrow \mathrm{HSS}=\mathrm{O} \quad \mathrm{HSS}=\mathrm{O}+{ }^{\circ} \mathrm{OH} \underset{\text { тиосульфит }}{\rightarrow} \mathrm{H}_{2} \mathrm{~S}_{2} \mathrm{O}_{2}
\end{gathered}
$$

Факт обнаружения в препаратах печени тиосульфата позволяет далее говорить об окислении тиосульфита до тиосульфата:

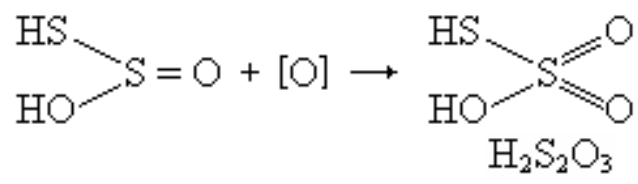

$$
\begin{array}{r}
\mathrm{H}_{2} \mathrm{~S}_{2} \mathrm{O}_{3} \rightleftarrows 2 \mathrm{H}^{+}+\mathrm{S}_{2} \mathrm{O}_{3}^{2-} \\
\text { тиосульфат-ион }
\end{array}
$$

Далее тиосульфат под действием глутатиона распадается на сульфид- и сульфит-ионы:

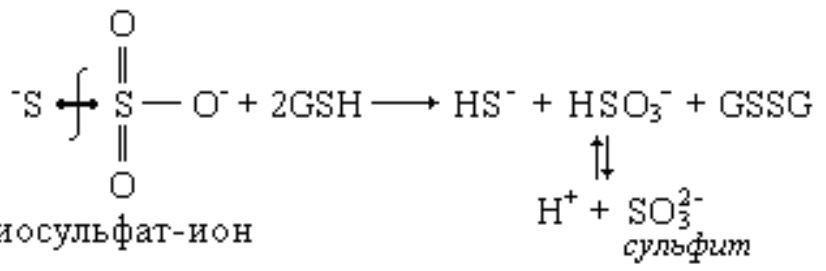

В печени и почках обнаружен фермент сульфитоксидаза, с помощью которого сульфит превращается в сульфат:

$$
\mathrm{SO}_{3}^{2-}+1 / 2 \mathrm{O}_{2} \stackrel{\text { суль фит-оксидаза }}{\longrightarrow} \mathrm{SO}_{4}^{2-}
$$

Анализируя механизм окисления сероводорода, нетрудно придти к заключению, что в процессе вышеописанных превращений генерируется огромное количество свободных радикалов и активизированных кислородных метаболитов - $\mathrm{HO}_{2}{ }^{*}, \mathrm{HO}^{*}, \mathrm{O}_{2}{ }^{\circ}$, способствующих развитию свободнорадикального окисления. 


\section{3.Морфофункциональное состояние семенников в условиях острого сероводородного отравления}

Контроль. У животных контрольной группы семенные канальцы на срезах имели округлую форму, тесно прилегая друг к другу. Обычно на каждом участке семенного канальца присутствовало 4 вида половых клеток, расположенных упорядоченно в соответствии со стадиями сперматогенного цикла. На базальной мембране семенных канальцев располагались клетки Сертели, образующие "футляр" для развивающихся сперматогенных клеток.

Между семенными канальцами, в интерстициальной ткани локализовались клетки Лейдига в количестве 7,46 0,505 на один каналец. Наблюдалось три типа гландулоцитов: малые, средние и большие. Функционально активные средние клетки Лейдига имели ядро округлой формы диаметром 4-7,28 мкм, располагающееся обычно эксцентрически. Данные клетки образовывали скопления угловатой формы по ходу сосудов. Количество средних клеток Лейдига составляло около $65 \%$ всей популяции.

СВСГ. У всех животных, подвергшихся воздействию сероводородсодержащим газом, наблюдались отек интерстициальной ткани и полнокровие сосудов. Семенные канальцы при поперечном срезе имели, в основном, округлую форму и располагались на значительном расстоянии друг от друга (рис. 2). У большей части особей данной группы наряду с отеком интерстициальной ткани отмечалось также скопление отечной жидкости внутри канальцев. При этом наблюдались разрывы соединительнотканной оболочки и некроз сперматогенного эпителия. 


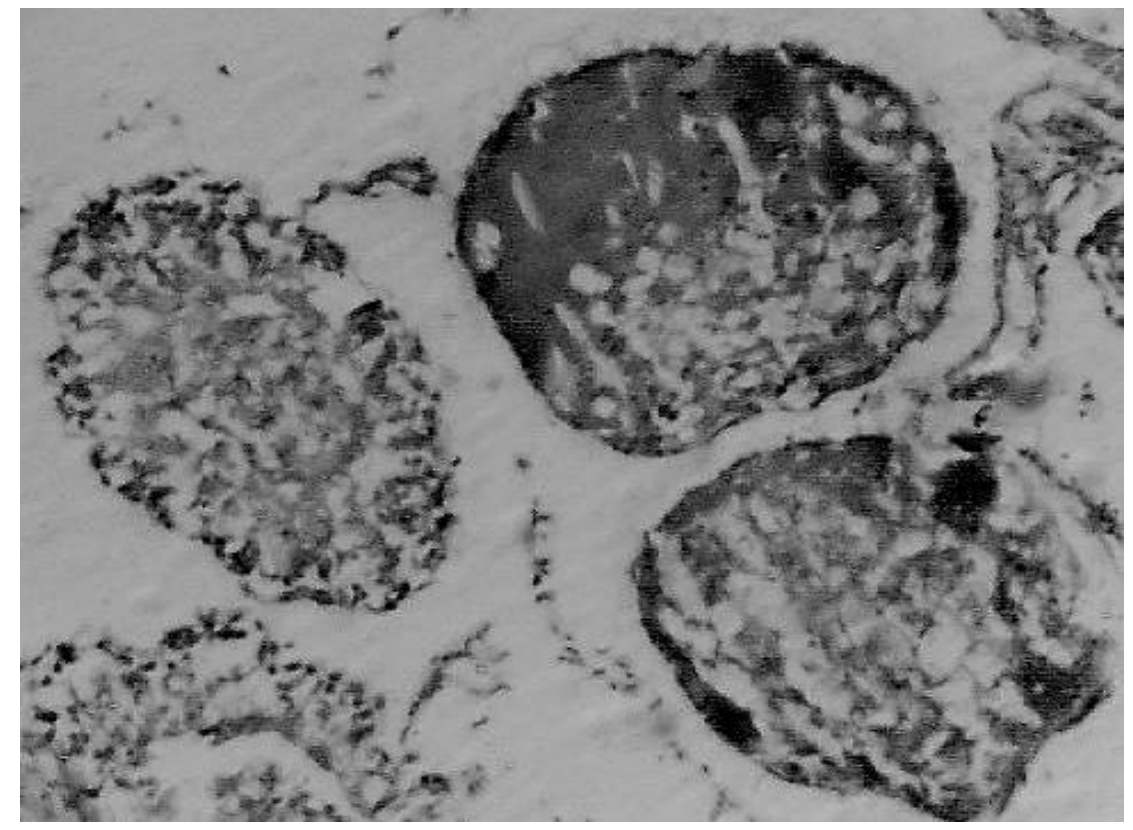

Рис. 2. Структура извитых канальцев семенников у животных, подвергнутых воздействию сероводородсодержащим газом. Окраска гематоксилин-эозином; увел.100х.

Б. Функциональное состояние репродуктивной системы самцов белых крыс в условиях хронического стресса

3.4.Состояние стероидогенеза и морфофункциональная характеристика семенников в условиях хронической сероводородной интоксикации

3.4.1. Состояние тестикулярного стероидогенеза самцов белых крыс в условиях хронического воздействия сероводородсодержащим газом АГКМ.

В гомогенате семенников определяли общую активность $\Delta^{5}-3 \beta$-гидроксистероиддегидрогеназы (ГСД) с помо- 
щью спектрофотометрического метода Рубина в модификации Голдмана (Резніков О.Г., Демченко В.М., Нищименко О.В., 1976). Активность ГСД выражали в ОУЕ (1 ОУЕ = 1 мкг образовавшегося за 90 мин продукта / 1 г ткани семенника). При хроническом воздействии сероводородсодержащего газа АГКМ отмечалось снижение общей активности ГСД более чем в 2 раза в сравнении с контролем $(\mathrm{P}<$ 0,001) (табл. 3).

Таблица 3

Активность $\Delta^{5}$-3及-гидроксистероиддегидрогеназы в семенниках крыс после хронического воздействия СВСГ АГКМ

\begin{tabular}{|c|c|c|}
\hline $\begin{array}{c}\text { Экспериментальные } \\
\text { группы }\end{array}$ & $\mathbf{n}$ & Активность ГСД, у.е. \\
\hline Контроль & 15 & $236,2 \pm 29,3$ \\
\hline Микроволновое излучение & 15 & $114,1 \pm 15,8$ \\
\hline $\begin{array}{l}\text { Сероводородсодержащий } \\
\text { газ АГКМ }\end{array}$ & 15 & $102,0 \pm 22,5$ \\
\hline
\end{tabular}

Таким образом, в условиях хронического воздействия сероводородсодержащим газом имеет место угнетение тестикулярного стероидогенеза, что можно объяснить как с позиций губительного усиления процессов радикалообразования в условиях развития окислительного стресса, так и с позиций эндокринных сдвигов в системе гипоталамусгипофиз.

\subsection{2. Морфофункциональная оценка ткани семенников и сперматогенных клеток в условиях многократ- ного воздействия сероводородсодержсацим газом.}

В условиях хронического воздействия сероводородсодержащим газом наблюдалось заметное уменьшение диаметров семенных канальцев на фоне резкого разрастания интерстициальной ткани за счёт главным образом прироста малых инволюционирующих функционально малоактивных клеток Лейдига отросчатой формы, что можно 
рассматривать как компенсаторную реакцию эндокриноцитов на фоне деструктивных изменений сперматогенного эпителия. Также имел место отёк интерстициальной ткани, полнокровие сосудов семенников и гибель половых клеток. Семенные канальцы располагались на значительном расстоянии друг от друга. Наблюдалось хаотичное расположение клеток сперматогенного эпителия (а в ряде случаев и вообще запустевание семенных канальцев) (рис. 3).

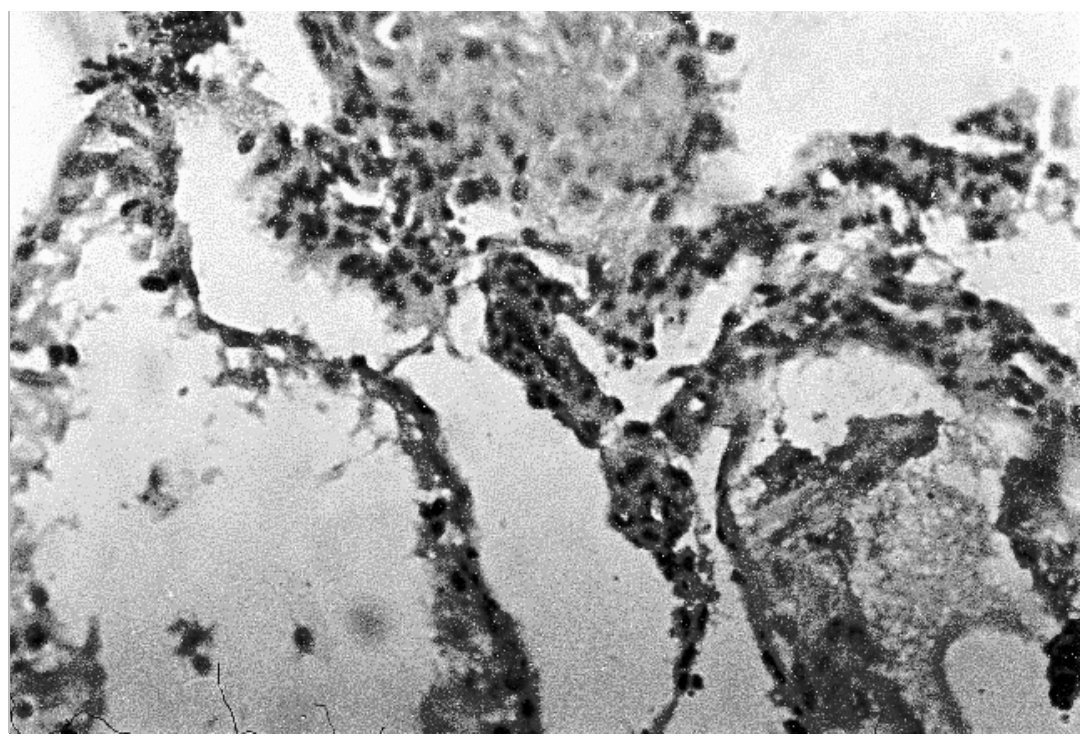

Рис. 3. Структура извитых канальцев семенников животных, подвергнутых воздействию сероводородсодержащим газом. Окраска гематоксилин-эозином. Увеличение 200x

Отмечается резкое уменьшение общего количества сперматогенных клеток в семеннике более чем в 7 раз по сравнению с контрольной группой. Наблюдалось выраженное нарушение соотношения между сперматогенными клетками (сперматогонии, сперматоциты, сперматиды, 
сперматозоиды). Содержание сперматогоний и сперматозоидов было сниженным, преобладали сперматоциты и сперматиды.

Общее количество эпидидимальных сперматозоидов было снижено более чем в 1,7 раз, в сравнении с контролем $(\mathrm{P}<0,001)$ (таблица 4).

В популяции сперматозоидов отмечалось увеличение процентного содержания дефективных форм (44,4 \%), подвижные сперматозоиды почти отсутствовали $(0,4 \%)$. Также почти в 11,5 раз увеличилось содержание мёртвых сперматозоидов $(55,2 \%)$ по сравнению с контролем $(4,8 \%)$ $(\mathrm{P}<0,001)$. Отсутствие подвижности сперматозоидов, очевидно, связано с таким дефектом, как облом хвоста сперматозоидов, что можно объяснить как результат усиления процесса липопероксидации в условиях развития окислительного стресса, вызванного сероводородсодержащим газом.

Таблица 4

Характеристика эпидидимальных сперматозоидов у крыс в норме и в условиях воздействия сероводородсодержащим газом

\begin{tabular}{|c|c|c|}
\hline $\begin{array}{c}\text { Показатели состояния } \\
\text { эпидидимальных } \\
\text { сперматозоидов }\end{array}$ & $\begin{array}{c}\text { Контроль } \\
(\mathrm{n}=10)\end{array}$ & $\begin{array}{l}\text { Воздействие сероводо- } \\
\text { родсодержащим газом } \\
(\mathrm{n}=10)\end{array}$ \\
\hline $\begin{array}{l}\text { Общее количество, } \\
\text { млн. }\end{array}$ & $50,0 \pm 6,51$ & $\begin{array}{c}* * * \\
28,4 \pm 2,44 \\
\end{array}$ \\
\hline Дефективные, \% & $20,2 \pm 2,22$ & $\begin{array}{c}* * * \\
44,4 \pm 3,83 \\
\end{array}$ \\
\hline Подвижные, \% & $81,0 \pm 6,2$ & $\begin{array}{c}* * * \\
0,4 \pm 0,12\end{array}$ \\
\hline Мёртвые, \% & $4,8 \pm 0,82$ & $\begin{array}{c}* * * * \\
55,2 \pm 4,11\end{array}$ \\
\hline
\end{tabular}


Проведённое исследование показало, что хроническое воздействие сероводородсодержащим газом вызывает угнетение как стероидо-, так и сперматогенеза.

\section{5.Состояние стероидо- и сперматогенеза в услови- ях многократного воздействия микроволнового излучения низкой интенсивности}

Самцов белых крыс массой 215-240 г подвергали воздействию микроволновым излучением с частотой 42 ГГц («Явь-1-7,1»; $\lambda=7,1$ мм) в течение 30 дней по 30 минут ежедневно. Эксперименты на животных осуществлялись в соответствии с требованиями Женевской конвенции (1985). По окончании экспериментальных воздействий в крови измеряли перекисный гемолиз эритроцитов (ПГЭ), а также исходный уровень малонового диальдегида (МДА) и кинетические показатели перекисного окисления липидов (ПОЛ) в тканях медиобазального гипоталамуса и семенников. Кроме того измеряли относительные массы гипофиза $($ мг\%) и семенников (\%). Уровни половых гомонов - тестостерона и лютропина - определяли методом иммуноферментного анализа. Уровень биосинтеза тестостерона оценивали посредством определения общей активности фермента биосинтеза тестостерона - $\Delta^{5}-3 \beta$ гидроксистероиддегидрогеназы (ГСД) в гомогенатах семенников. Срезы семенников толщиной 7 мкм изготавливали на микротоме "Microm HМ - 400" (Германия). Срезы окрашивали гематоксилин-эозином. Полученные препараты изучались на универсальном микроскопе "Nu" (Германия), соединенным с цветной телевизионной камерой "Ріхera" (США). Определяли продольные и поперечные диаметры семенных канальцев, количество клеток Лейдига из расчета на один каналец, а также площадь ядер средних 
клеток Лейдига; исследовали морфо-кинетические свойства эпидидимальных сперматозоидов.

Под действием электромагнитного излучения указанной частоты зафиксировано достоверное усиление перекисного гемолиза эритроцитов, в сравнении с контролем $(50,2 \pm 2,21$ и 42,2 $\pm 3,49 \%$ соответственно), что свидетельствует об усилении свободнорадикальных окислительных процессов в крови и развитии оксидативного стресса. Развитие окислительного стресса, сопряжённого с радикальным окислением ненасыщенного фосфолипида RH, можно выразить следующей схемой:

$$
\begin{aligned}
& \mathrm{RH}^{\circ}+\mathrm{O}_{2} \rightarrow \mathrm{RO}_{2} \stackrel{+\mathrm{RH}}{\rightarrow} \mathrm{ROOH} \\
& \mathrm{RO}^{\circ}+\mathrm{RH} \rightarrow \mathrm{ROH}+\mathrm{R}^{\circ}
\end{aligned}
$$

Усиление процессов свободнорадикального окисления (СРО) может означать ухудшение функционального состояния систем организма. В условиях воздействия микроволнового излучения (МВИ) в ткани семенников отмечалось усиление динамики процессов СРО. Исходный уровень МДА возрос почти на 38,5 \%, по сравнению с контрольными значениями (табл. 5). Кинетические показатели ПОЛ в условиях вызванного стресса также достоверно возрастали, особенно асПОЛ.

Таблица 5

Изменение показателей липопероксидации в ткани семенников в условиях воздействия микроволнового излучения

\begin{tabular}{|l|c|c|c|c|}
\hline \multirow{2}{*}{$\begin{array}{c}\text { Условия опы- } \\
\text { та }\end{array}$} & $\mathrm{n}$ & \multirow{2}{*}{$\begin{array}{c}\text { МДА }_{\text {исх }}, \\
\text { нмоль } / 0,05 \text { г }\end{array}$} & \multicolumn{2}{|c|}{$\begin{array}{c}\text { Кинетические показатели, } \\
\text { нмоль МДА/ч }\end{array}$} \\
\cline { 4 - 5 } & & спПОЛ & асПОЛ \\
\hline Контроль & 10 & $4,89 \pm 0,151$ & $45,97 \pm 0,840$ & $48,74 \pm 0,702$ \\
\hline МВИ & 10 & $6,77 \pm 0,272$ & $48,32 \pm 2,003$ & $55,21 \pm 0,894$ \\
\hline \multicolumn{1}{|c|}{ Р } & & $\mathrm{P}<0,001$ & $\mathrm{P}>0,05$ & $\mathrm{P}<0,001$ \\
\hline
\end{tabular}


Под влиянием микроволнового излучения низкой интенсивности относительная масса семенников достоверно не изменяется, что говорит об относительно нейтральном внешнем эффекте данного стресс-фактора. Относительная масса гипофиза также менялась незначительно в результате воздействия микроволнового излучения. Таким образом, внешне данный физический стресс-фактор не оказал заметного влияния на сам гипофизарно-семенниковый комплекс. Вместе с тем, была исследована инкреторная функция гипофизарно-семенникового комплекса. В контрольной группе уровень тестостерона у животных составил величину $2,829 \pm 0,0731$ нг/мл. Под влиянием микроволнового излучения уровень тестостерона имел тенденцию к снижению и составил величину $2,614 \pm 0,1160$ нг/мл и достоверно не отличался от контрольного значения. Уровень лютропина практически не отличался от контрольного значения, что свидетельствует об отсутствии регуляторного влияния со стороны гипоталамо-гипофизарного комплекса на инкреторную функцию гонад в условиях проводимого эксперимента. В то же самое время уровни тестостерона и лютеинизирующего гормона коррелировали между собой в соответствии с коэффициентом положительной корреляции $\mathrm{r}=+0,634$, что свидетельствует о слаженном механизме регуляции инкреторной функции гонад в условиях экспериментальных воздействий (табл. 6).

Таблица 6

Изменение уровней тестостерона и лютеинизирующего гормона в условиях воздействия низкоинтенсивного МВИ

\begin{tabular}{|c|c|c|c|c|}
\hline $\begin{array}{c}\text { Условия } \\
\text { опыта }\end{array}$ & $\mathrm{n}$ & $\begin{array}{c}\text { Тестостерон, } \\
\text { нг/мл }\end{array}$ & $\begin{array}{c}\text { Лютеинизирующий } \\
\text { гормон, мМЕ/мл }\end{array}$ & $\begin{array}{c}\text { Коэффициент } \\
\text { корреляции, } \mathrm{r}\end{array}$ \\
\hline Контроль & 6 & $2,829 \pm 0,0731$ & $0,425 \pm 0,0538$ & $+0,935$ \\
\hline МВИ & 6 & $2,614 \pm 0,1160$ & $0,420 \pm 0,0068$ & $+0,634$ \\
\hline $\mathrm{P}$ & & $\mathrm{P}>0,05$ & $\mathrm{P}>0,05$ & \\
\hline
\end{tabular}


Активность фермента ГСД под влиянием микроволнового излучения достоверно не изменилась, по сравнению с контрольным показателем $(214,1 \pm 15,81$ и $236,2 \pm 29,33$ у.е. соответственно), что также подтверждает факт отсутствия видимых изменений со стороны тестостеронпродуцирующей активности семенников в условиях экспериментального воздействия.

В результате воздействия излучения было зафиксировано снижение общего количества сперматогенных клеток, в сравнении с контролем $(3140 \pm 655$ и $5236 \pm 470$ млн. соответственно). Кроме того, отмечался дисбаланс между разными типами сперматогенных клеток.

Предварительные результаты настоящего исследования позволяют говорить о том, что наиболее уязвимыми к воздействию микроволн оказались сперматогонии-А, относительный уровень которых был заметно снижен по сравнению с контрольной группой.

Под влиянием ЭМИ указанной частоты отмечался прирост общего количества клеток Лейдига на $42 \%$, в сравнении с контролем (Р < 0,001), причем пролиферация происходила за счет главным образом средних клеток. Вместе с тем, площадь средних клеток имела тенденцию к снижению, по сравнению с аналогичным показателем контрольной группы $\left(15,3 \pm 1,03\right.$ и $16,5 \pm 2,31$ мкм $^{2}$ соответственно). Все это объясняет факт практически неотличимой от контроля тестостеронпродуцирующей активности семенников белых крыс, подвергавшихся воздействию низкоинтенсивного микроволнового излучения. Вместе с тем, к концу экспериментальных воздействий у животных отмечалось некоторое снижение общего количества эпидидимальных сперматозоидов на фоне прироста дефективных форм в 1,7 раз, в сравнении с контролем (Р $<0,01)$. Таким образом, под влиянием низкоинтенсивного ЭМИ отмеча- 
лось угнетение сперматогенеза на фоне пролиферации лейдиговских клеток.

\section{Вопросы для обсуждения}

1. Перечислите основные последствия острого отравления сероводородсодержащим природным газом в отношении репродуктивной системы самцов экспериментальных животных.

2. Перечислите основные последствия многократного воздействия сероводородсодержащим природным газом на репродуктивную систему самцов экспериментальных животных.

3. Последствия воздействия низкоинтенсивного электромагнитного излучения на мужскую репродуктивную систему.

\section{Самое важное в 3 главе}

Резюмируя полученные данные, можно отметить следующее.

1. Под влиянием однократного воздействия сероводородсодержащим газом АГКМ наблюдается развитие окислительного стресса, что выражается в усилении перекисного гемолиза эритроцитов и снижении относительной массы надпочечников.

2. Острая сероводородная интоксикация вызывает усиление процессов СРО и повышение окислительновосстановительного потенциала ткани семенников.

3. Под действием СВСГ снижается секреция тестостерона и ЛГ в крови.

4. Усиление процессов СРО в области медиобазального гипоталамуса в условиях воздействия сероводородсодержащего газа указывает на взаимосвязь угнетения функционального состояния семенников и гипоталамо- 
гипофизарного комплекса. Последнее обстоятельство свидетельствует о чётком контроле секреции тестостерона со стороны гипоталамо-аденогипофизарного комплекса в условиях интоксикации газом. Вместе с тем, усиление процессов СРО в ткани семенников свидетельствует также о непосредственном влиянии токсических эффектов сероводородсодержащего газа на функциональное состояние гонад.

5. Острое и хроническое воздействие сероводородсодержащим газом вызывает выраженные морфофункциональные нарушения ткани семенников белых крыс (интерстициальный отек, гемодинамические нарушения, некроз сперматогенного эпителия). В условиях хронического воздействия газом отмечается компенсаторное разрастание интерстициальной ткани за счет прироста малых функционально слабых клеток Лейдига.

6. Под влиянием низкоинтенсивного электромагнитного излучения (микроволнового излучения) отмечалось угнетение сперматогенеза на фоне пролиферации лейдиговских клеток.

7. Низкоинтенсивное электромагнитное излучение миллиметрового диапазона практически не влияет на тестостеронпродуцирующую активность семенников.

8. Длительное низкоинтенсивное электромагнитное излучение истощает ресурс пролиферации половых клеток. За счет усиления динамики процессов СРО и эффекта резонанса возможно отрицательное влияние указанного излучения на быстро пролиферирующие и незрелые половые клетки. 


\section{Глава 4. Коррекция сперматогенеза с помощью селена у крыс в условиях стресса}

\section{1. Теоретическое обоснование использования се- ленсодержащих биокомплексов в условия стресса.}

Хронический стресс изучали на модели воздействия сероводородсодержащего газа и микроволнового излучения низкой интенсивности. Учитывая, что селен обладает корректирующими свойствами в отношении сперматозоидов (Полунин А.И., Луцкий Д.Л., Мирошников В.М. и др., 2002), нами был выбран селен в органической форме (селексен), обогащённый аскорбиновой кислотой, которая усиливает протекторные свойства селена. В нашем исследовании самцам белых крыс перорально вводили селексен и аскорбиновую кислоту соответственно в дозах 1,5 и 500 мг/кг массы тела животного 1 раз в сутки в течение 50 дней, а через 14 дней на фоне введения селенсодержащего биокомплекса воздействовали микроволновым излучением с частотой 42 ГГц $(\lambda=7,1$ мм) в течение 30 дней по 30 минут ежедневно или сероводородсодержащим газом в концентрации $10 \mathrm{мг} / \mathrm{M}^{3}$ в течение 30 дней по 240 минут ежедневно. Затем исследовали морфологические и кинетические показатели эпидидимальных сперматозоидов. Для этого по окончании опытов из хвостовой части эпидидимисов, разрезая их вдоль, вымывали семенную жидкость дозированным количеством физиологического раствора (эмпирически для крыс это количество 2-4 мл) (Саноцкий И.В., Фоменко В.Н., 1979) и получали суспензию (эпидидимальные сперматозоиды у животных третьей группы выделяли на 7-й день после окончания воздействия микроволновым излучением). На часовом стекле в течение 2 минут эпидидимис активно перемещали для освобождения от 50 
части сперматозоидов (во избежание артефактов стеклянные палочки применять нельзя, используют отрезки отмытой резиновой трубки). Взвесь сперматозоидов наносили на предметные стёкла, подсушивали на воздухе, фиксировали над пламенем и окрашивали любым красителем. Подсчёт дегенеративных форм вели по отношению к количеству просчитанных в полях зрения сперматозоидов. Подсчёт общего числа эпидидимальных сперматозоидов в суспензии производили в камере Горяева под окуляром светового микроскопа при увеличении 400x. Число спермиев подсчитывали в 5 больших квадратах камеры Горяева по диагонали. Кроме того в нативной сперме определялось процентное соотношение между различными морфологическими формами сперматозоидов (дефективные, подвижные и мёртвые). Дополнительно для подтверждения количественных показателей давалась общая характеристика морфофункционального состояния семенных канальцев на основе гистологических срезов. Срезы семенников толщиной 7 мкм изготавливали на микротоме "Microm HМ - 400" (Германия). Срезы окрашивали гематоксилин-эозином. Полученные препараты изучались на универсальном микроскопе "Nu" (Германия), соединенным с цветной телевизионной камерой "Pixera" (США).

В качестве корректора был выбран селексен, поскольку селен в нем находится в хорошо усвояемой органической форме. Кроме того, в органической форме селен малотоксичен (Саноцкий И.В., 2001). В настоящее время доказано наличие синергизма селена и аскорбиновой кислоты, а также способность последней выводить избыток селена (Behne D., 1995). Животным вводили селен из расчёта 350 мкг селена на 1 кг массы тела животного в сутки, что адекватно для половозрелых крыс с точки зрения уровня их метаболизма (Ушакова М.В., 2002). Аскорбиновую 
кислоту давали животным в умеренно повышенной дозе, опираясь на ещё давние исследования Л. Полинга и его школы о роли высоких доз витамина С в регуляции физиологических процессов и, в том числе, репродуктивных (Полинг Л., 1974). Витамин С улучшает «качество» спермы, благотворно влияет на андрогенез и увеличивает подвижность сперматозоидов (Sharaf A., Gomaa N., 1970; Yousef M.I., Abdallah G.A., Kamel K.I., 2003). Высокие дозы витамина С трансформируют селенит натрия (неорганический селен) в практически неусваиваемый элементарный селен, выводящийся с фекалиями, чего не наблюдается в случае селена в органической форме. Это также определило выбор нами именно селексена в качестве источника селена. Сама аскорбиновая кислота, кроме того, способна регулировать уровень селена в организме и выводить его избыток из организма (Behne D. et al., 1995).

Селексен в сочетании с витамином С вводили один раз в сутки в указанных дозах, что полностью покрывало суточную потребность животных в данных нутриентах, которые равномерно распределялись в течение суток по всему организму. Учитывая, что сперматогенный цикл у крыс составляет 48 дней (ВО3, 1967), животным была назначена 50-дневная диета, обогащённая селексеном и витамином С. Через 2 недели после начала введения аскорбиновой кислоты и селексена начали воздействовать сероводородсодержащим газом в концентрации 10 мг/м ${ }^{3}$. Указанная концентрация газа в экспозиции до нескольких часов в сутки в течение длительного срока (обычно более двух недель) определяет квалификационную категорию воздействия «хроническая интоксикация» (Асфандияров Р.И., Бучин В.Н., Лазько А.Е. и др., 1995). Само воздействие сероводородсодержащим газом осуществлялось «внутри» самого курса введения селексена и аскорбиновой кислоты (с третьей не- 
дели в течение 30 дней), что позволяло плавно ввести токсикант в экспериментальную модель, избежав, таким образом, погрешностей, вызванных токсическими эффектами газа в отсутствие корректоров (селексена и аскорбиновой кислоты).

\section{2. Коррекция сперматогенеза в условиях воздейст- вия микроволнового излучения}

Количество и морфофункциональные показатели эпидидимальных сперматозоидов у белых крыс в норме и в условиях экспериментальных воздействий отражены в таблице 7. У животных, подвергнутых воздействию микроволнового излучения, отмечено сокращение общего количества эпидидимальных сперматозоидов в 1,5 раза, в сравнении с контролем $(\mathrm{P}<0,05)$.

Таблица 7

Морфологические и кинетические показатели эпидидимальных сперматозоидов у крыс, подверженных воздействию микроволнового излучения и потреблявших селенсодержащий биокомплекс

\begin{tabular}{|c|c|c|c|c|}
\hline $\begin{array}{c}\text { Показатели } \\
\text { состояния } \\
\text { эпидиди- } \\
\text { мальных } \\
\text { спермато- } \\
\text { зоидов } \\
\end{array}$ & $\begin{array}{c}\text { Контроль } \\
(\mathrm{n}=10)\end{array}$ & $\begin{array}{c}\text { Биоком- } \\
\text { плекс } \\
\text { (селексен + } \\
\text { витамин C) } \\
(\mathrm{n}=10)\end{array}$ & $\begin{array}{c}\text { Воздействие } \\
\text { микроволно- } \\
\text { вым излучени- } \\
\text { ем } \\
\text { (n = 10) }\end{array}$ & $\begin{array}{c}\text { Воздейст- } \\
\text { вие излу- } \\
\text { чением + } \\
\text { биоком- } \\
\text { плекс } \\
(\mathrm{n}=10) \\
\end{array}$ \\
\hline $\begin{array}{l}\text { Общее ко- } \\
\text { личество, } \\
\text { млн. }\end{array}$ & $50,0 \pm 6,51$ & $54,3 \pm 6,00$ & $\begin{array}{c}* \\
34,1 \pm 1,38\end{array}$ & $\begin{array}{c}\Delta \Delta \\
53,2 \pm 4,83\end{array}$ \\
\hline $\begin{array}{l}\text { Дефектив- } \\
\text { ные, \% }\end{array}$ & $18,2 \pm 2,22$ & $\begin{array}{c}* * \\
13,1 \pm 0,62\end{array}$ & $\begin{array}{c}* * \\
30,5 \pm 2,45 \\
\end{array}$ & $\begin{array}{c}\Delta \Delta \\
21,2 \pm 1,23\end{array}$ \\
\hline $\begin{array}{l}\text { Подвиж- } \\
\text { ные, \% }\end{array}$ & $81,0 \pm 6,20$ & $88,0 \pm 6,11$ & $\begin{array}{c}* * \\
60,1 \pm 2,65 \\
\end{array}$ & $66,4 \pm 2,77$ \\
\hline $\begin{array}{l}\text { Мёртвые, } \\
\%\end{array}$ & $9,8 \pm 0,82$ & $\begin{array}{c}* * * \\
4,7 \pm 0,72\end{array}$ & $\begin{array}{c}* * * \\
30,2 \pm 1,21\end{array}$ & $\begin{array}{c}\Delta \Delta \Delta \\
17,4 \pm 0,98\end{array}$ \\
\hline
\end{tabular}


Количество дефективных сперматозоидов (30,5 \%) возросло в 1,7 раз, в сравнении с контролем $(18,2 \%)$. Количество мёртвых сперматозоидов возросло в 3 раза $(30,2 \%)$ по сравнению с контролем $(9,8 \%)(\mathrm{P}<0,001)$. Отсутствие подвижности сперматозоидов в основном связано с таким дефектом, как облом хвоста, что можно объяснить усилением процесса липопероксидации в условиях воздействия микроволнового излучения. Потребление селенсодержащего биокомплекса вызвало улучшение подвижности и способствовало повышению количества эпидидимальных сперматозоидов, по сравнению с контрольной группой животных. Количество мёртвых сперматозоидов снижалось более чем в 2 раза, по сравнению с контролем ( $<<0,001)$. Улучшение кинетических свойств и жизнеспособности сперматозоидов при приёме указанного биокомплекса можно объяснить тем фактом, что в хвосте сперматозоидов крыс содержится селенопептид, который имеет важное структурное значение при сборке хвоста сперматозоидов (Ушакова М.В., 2002). Вместе с тем, предварительное потребление животными селенсодержащего биокоимплекса способствовало снижению деструктивных последствий микроволнового излучения. Достоверно значимых отклонений от контроля по количеству сперматозоидов у животных, подвергавшихся воздействию микроволновым излучением и предварительно получавших указанный биопротектор, нами не было зафиксировано. Отмечалась тенденция к увеличению общего количества эпидидимальных сперматозоидов. Количество дефективных сперматозоидов в группе животных, подвергавшихся воздействию микроволнового излучения на фоне приёма селенсодержащего биокомплекса, не отличалось достоверно от такового контрольной группы. Селенсодержащий биокомплекс способствовал некоторому улучшению подвижности спермато- 
зоидов в условиях воздействия микроволнового излучения, по сравнению с группой животных, подвергавшихся только воздействию излучения. Количество мёртвых сперматозоидов было заметно ниже в условиях воздействия микроволнового излучения на фоне приёма биокомплекса, по сравнению с группой животных, подвергавшихся воздействию только излучения, хотя и не достигало контрольных значений.

Структура извитых канальцев семенников животных, подвергнутых воздействию микроволнового излучения, отражена на рисунке 4.

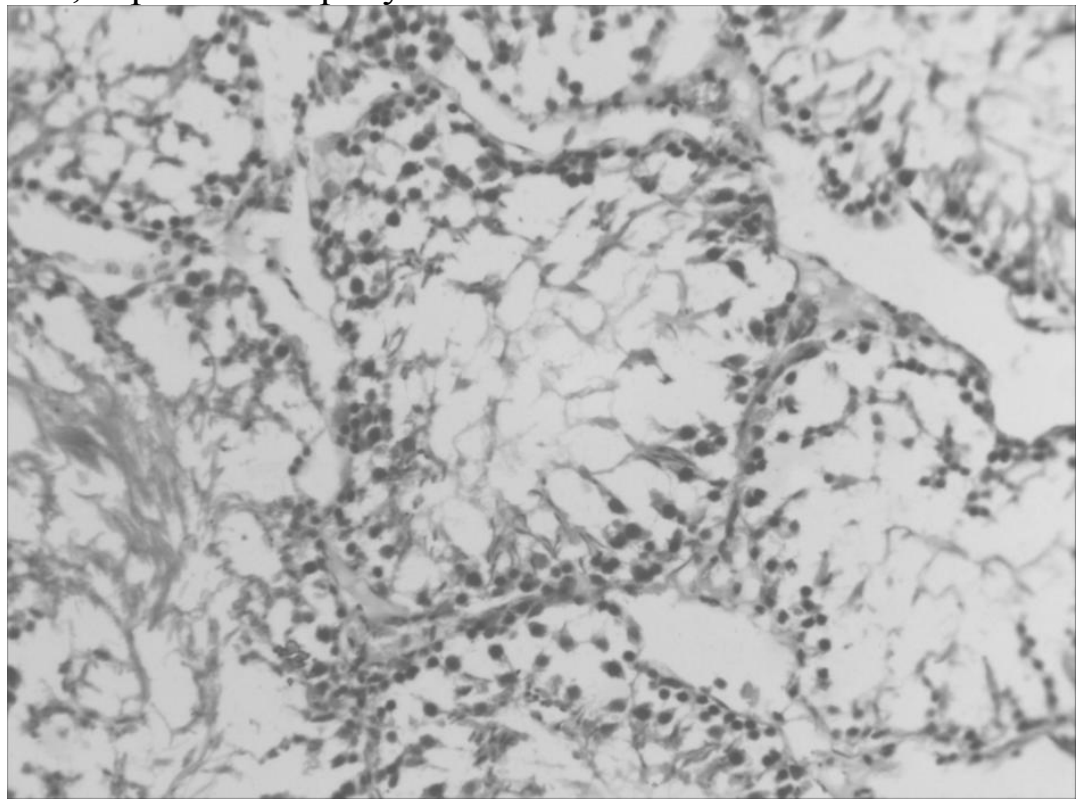

Рис. 4. Структура извитых канальцев семенников крыс в условиях воздействия микроволнового излучения. Окраска гематоксилин-эозином. Увел. 200x.

В условиях воздействия микроволнового излучения наблюдалось полнокровие сосудов семенников и общее 
снижение половых клеток. Наблюдалось хаотичное расположение клеток сперматогенного эпителия на фоне в ряде случаев отслоения базальной мембраны. В отдельных случаях наблюдались множественные разрывы базальной мембраны, запустевание семенных канальцев, либо неравномерная высота сперматогенного эпителия, что в целом позволяет говорить о признаках некроза сперматогенного эпителия. Структура извитых канальцев семенников животных, подвергнутых воздействию микроволнового излучения и получавших предварительно селенсодержащий биокомплекс, отражена на рисунке 5. Сами семенные канальцы имеют правильную округлую форму.

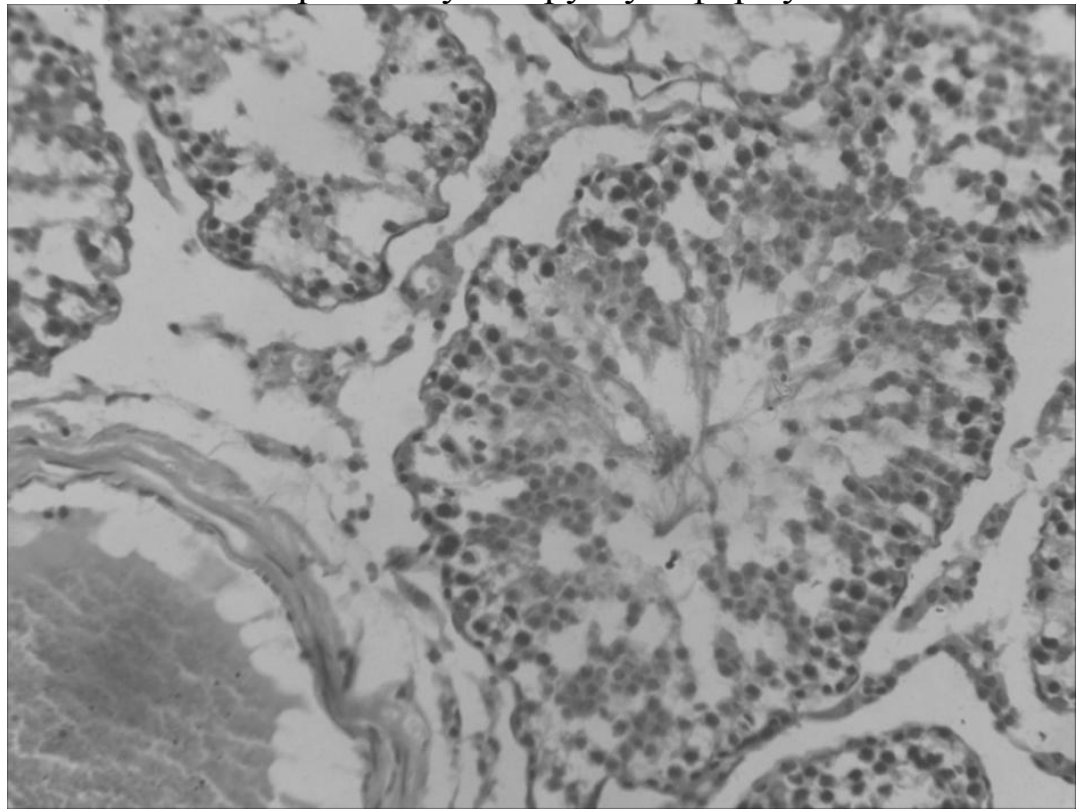

Рис. 5. Структура семенных канальцев крыс, подвергавшихся воздействию микроволнового излучения и получавших селенсодержащий биокомплекс.

Окраска гематоксилин-эозином. Увел. 200x. 
Предварительное введение биокомплекса способствовало заметному снижению деструктивных эффектов, вызываемых одним только микроволновым излучением. Семенные канальцы заполнены разными типами сперматогенных клеток. Ближе к просвету семенных канальцев можно видеть сперматозоиды. Таким образом, можно заключить, что селенсодержащий биокомплекс в условиях воздействия микроволнового излучения низкой интенсивности способствовал улучшению морфофункциональных показателей эпидидимальных сперматозоидов.

\section{3. Коррекция сперматогенеза в условиях хрониче- ского воздействия природным газом}

Количество и морфофункциональное состояние эпидидимальных сперматозоидов у крыс в норме и в условиях экспериментальных воздействий отражено в табл. 8.

Таблица 8

Морфологические и кинетические показатели эпидидимальных сперматозоидов крыс, подверженных воздействию сероводородсодержащим газом и потреблявших селенсодержащий биокомплекс

\begin{tabular}{|c|c|c|c|c|}
\hline $\begin{array}{c}\text { Показатели } \\
\text { состояния } \\
\text { эпидиди- } \\
\text { мальных } \\
\text { спермато- } \\
\text { зоидов }\end{array}$ & $\begin{array}{c}\text { Контроль } \\
(\mathrm{n}=10)\end{array}$ & $\begin{array}{c}\text { Биоком- } \\
\text { плекс } \\
\text { (селексен + } \\
\text { витамин C) } \\
(\mathrm{n}=10)\end{array}$ & $\begin{array}{l}\text { Воздейст- } \\
\text { вие серово- } \\
\text { дородсо- } \\
\text { держащим } \\
\text { газом } \\
(\mathrm{n}=10)\end{array}$ & $\begin{array}{c}\text { Воздейст- } \\
\text { вие газом + } \\
\text { биоком- } \\
\text { плекс } \\
(\mathrm{n}=10)\end{array}$ \\
\hline $\begin{array}{l}\text { Общее ко- } \\
\text { личество, } \\
\text { млн. }\end{array}$ & $50,0 \pm 6,51$ & $54,3 \pm 6,0$ & $\begin{array}{c}* * * \\
28,4 \pm 2,44\end{array}$ & $\begin{array}{c}\Delta \Delta \\
41,0 \pm 4,51\end{array}$ \\
\hline $\begin{array}{l}\text { Дефектив- } \\
\text { ные, \% }\end{array}$ & $20,2 \pm 2,22$ & $\begin{array}{c}* * * \\
13,1 \pm 0,62 \\
\end{array}$ & $\begin{array}{c}* * * \\
44,4 \pm 3,83\end{array}$ & $\begin{array}{c}\Delta \Delta \Delta \\
42,0 \pm 3,52 \\
\end{array}$ \\
\hline $\begin{array}{l}\text { Подвиж- } \\
\text { ные, \% }\end{array}$ & $81,0 \pm 6,2$ & $88,0 \pm 6,11$ & $\begin{array}{c}* * * \\
0,4 \pm 0,12\end{array}$ & $\begin{array}{c}\Delta \Delta \Delta \\
54,5 \pm 4,22 \\
\end{array}$ \\
\hline $\begin{array}{l}\text { Мёртвые, } \\
\%\end{array}$ & $4,8 \pm 0,82$ & $4,7 \pm 0,72$ & $\begin{array}{c}* * * \\
55,2 \pm 4,11\end{array}$ & $45,4 \pm 3,31$ \\
\hline
\end{tabular}

Условные обозначения аналогичны таковым в табл. 7. 
У животных, подвергнутых воздействию газом, на 7-й день после прекращения воздействия таковым отмечено резкое уменьшение общего количества эпидидимальных сперматозоидов более чем в 1,7 раз, в сравнении с контролем $(\mathrm{P}<0,001)$. В популяции сперматозоидов отмечалось увеличение процентного содержания дефективных форм (44,4\%), подвижные сперматозоиды почти отсутствовали (0,4\%). Также почти в 11,5 раз увеличилось содержание мёртвых сперматозоидов $(55,2 \%)$ по сравнению с контролем $(4,8 \%)$ ( $<0,001)$. Отсутствие подвижности сперматозоидов связано с таким дефектом, как облом хвоста сперматозоидов, что можно объяснить усилением процесса липопероксидации в условиях развития окислительного стресса, вызванного сероводородсодержащим газом. Вместе с тем, предварительное потребление животными селенсодержащего биокоимплекса способствовало снижению токсических эффектов сероводородсодержащего газа.

Селен обладает большим сходством с серой. Их атомы имеют близкую конфигурацию наружных электронных оболочек, почти одинаковые размеры и сходные ионизационные потенциалы. Селен входит в состав селенопептида, участвующего в сборке хвоста сперматозоидов (Ушакова М.В., 2002). В этой связи вполне естественным представляется тот факт, что дефицит селена вызывает нарушение репродуктивной функции.

В группе животных, подвергавшихся воздействию газом и предварительно получавших селенсодержащий комплекс, наблюдалось некоторое улучшение соотношения между разными формами сперматогенных клеток в сравнении с группой животных, подвергавшихся воздействию только газом.

Структура извитых канальцев семенников животных, подвергнутых воздействию сероводородсодержащим 
газом, отражена на рисунке 6. В условиях воздействия сероводородсодержащим газом наблюдался отёк интерстициальной ткани, полнокровие сосудов семенников и гибель половых клеток. Семенные канальцы располагались на значительном расстоянии друг от друга. Наблюдалось отслоение базальной мембраны и хаотичное расположение клеток сперматогенного эпителия, запустевание семенных канальцев).

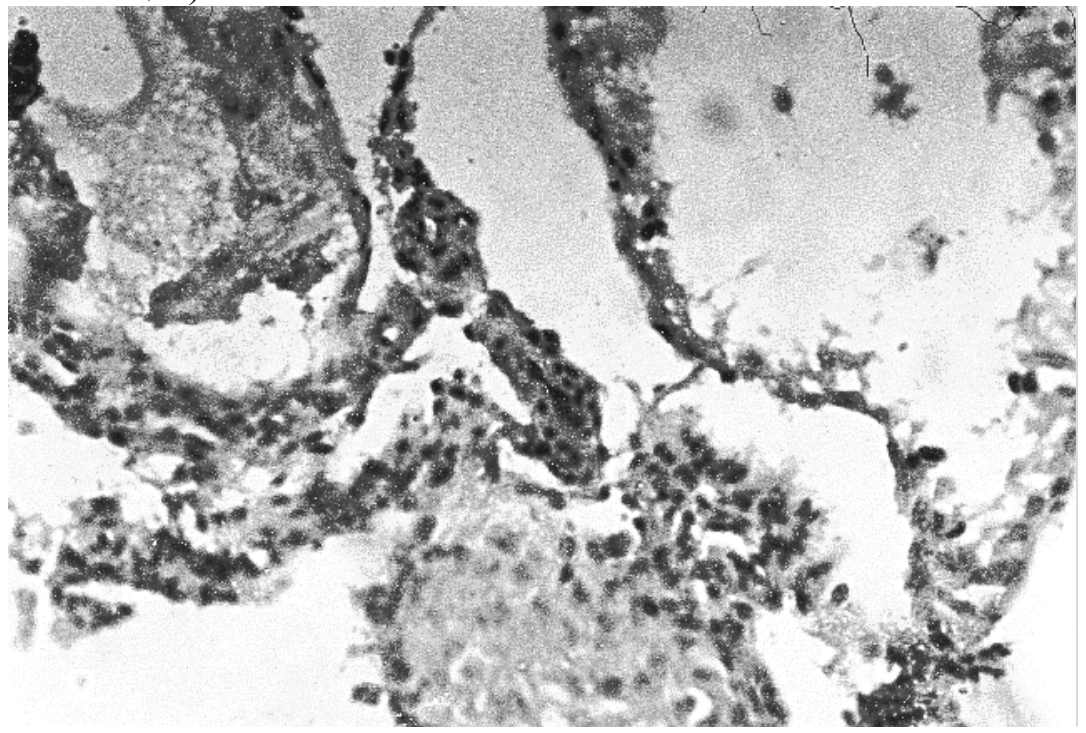

Рис. 6. Структура извитых канальцев семенника в условиях воздействия сероводородсодержащим газом. Окраска гематоксилин-эозином. Увел. 200x.

Структура извитых канальцев семенников животных, подвергнутых воздействию газом и получавших предварительно селексен в сочетании с витамином C, отражена на рисунке 7. Предварительное введение селенсодержащего биокомплекса способствует заметному снижению токсических эффектов, вызываемых одним токсикантом. 


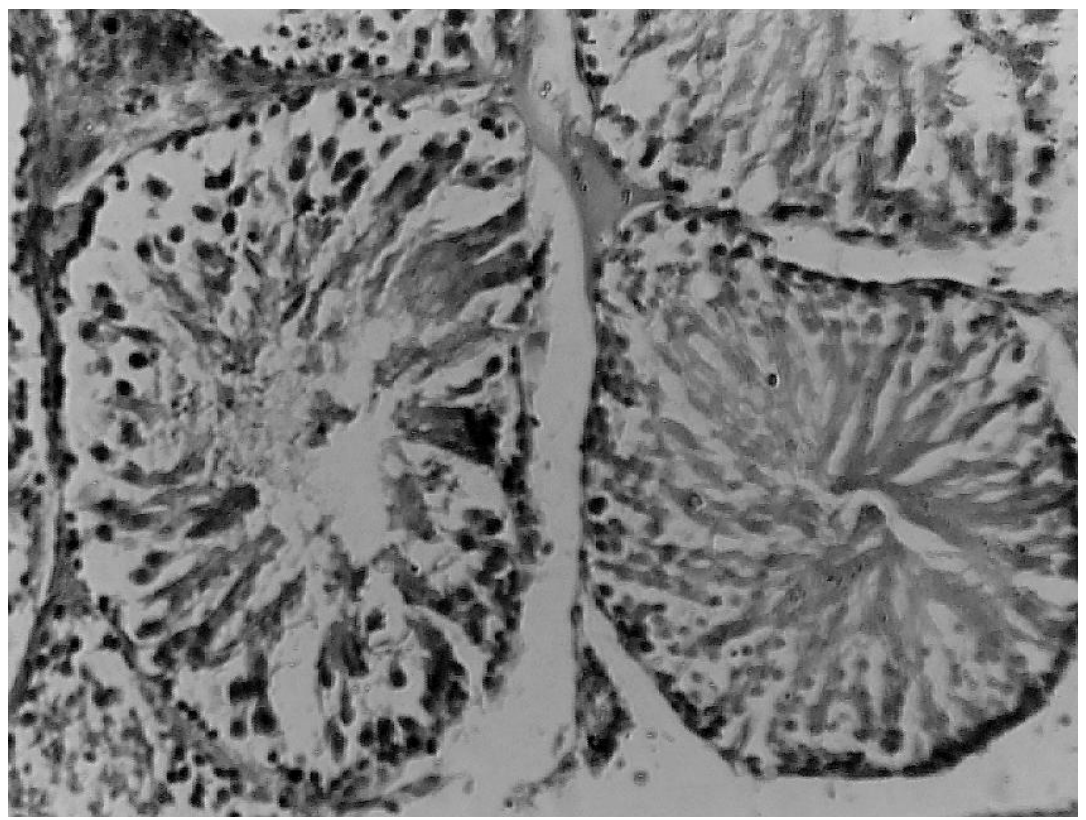

Рис. 7. Структура извитых канальцев семенников крыс, подвергавшихся воздействию сероводородсодержащим газои и получавших селенсодержащий биокомплекс.

Окраска гематоксилин-эозином. Увел. 200x.

Все вышеуказанные обстоятельства свидетельствует в пользу протекторных свойств селексена в сочетании с повышенными дозами аскорбиновой кислоты в отношении мужской репродуктивной функции в условиях экстремальных воздействий сероводородсодержащих поллютантов, вызывающих развитие оксидативного стресса. 


\section{Вопросы для обсуждения}

1. Почему селен в органической форме наиболее предпочтителен для его использования в качестве биопротектора?

2. Каковы молекулярные механизмы протекторного действия селена в отношении мужской репродуктивной системы?

3. В чем состоит взаимосвязь селена и аскорбиновой кислоты?

4. Какие селенсодержащие биокомплексы можно смоделировать?

5. По каким критериям следует подбирать дозировку препаратов селена и длительность их применения?

6. Корректирующие эффекты селена в условиях хронической интоксикации сероводородсодержащим газом в отношении репродуктивной системы.

7. Каковы результаты использования органического селена в условиях хронического воздействия микроволнового излучения низкой интенсивности?

8. Каков общий механизм протекторного действия селенсодержащих комплексов в отношении мужской репродуктивной системы?

\section{Самое важное в 4 главе}

1. Потребление селенсодержащего биокомплекса вызвало улучшение подвижности и способствовало повышению количества эпидидимальных сперматозоидов, по сравнению с контрольной группой животных. Количество мёртвых сперматозоидов снижалось более чем в 2 раза, по сравнению с контролем (P < 0,001).

2. Предварительное потребление животными селенсодержащего биокоимплекса способствовало снижению де- 
структивных последствий микроволнового излучения. Достоверно значимых отклонений от контроля по количеству сперматозоидов у животных, подвергавшихся воздействию микроволновым излучением и предварительно получавших указанный биопротектор, не было зафиксировано.

3. Селенсодержащий биокомплекс способствовал некоторому улучшению подвижности сперматозоидов в условиях воздействия микроволнового излучения, по сравнению с группой животных, подвергавшихся только воздействию излучения.

4. В группе животных, подвергавшихся воздействию газом и предварительно получавших селенсодержащий комплекс, наблюдалось некоторое улучшение соотношения между разными формами сперматогенных клеток в сравнении с группой животных, подвергавшихся воздействию только газом. Предварительное введение селенсодержащего биокомплекса способствует заметному снижению токсических эффектов, вызываемых одним токсикантом.

Таким образом, селенсодержащий биокомплекс способствовал достоверному снижению токсических эффектов, вызываемых Астраханским природным газом и низкоинтенсивным микроволновым излучением. Аскорбиновая кислота способствовала усилению протекторных свойств селексена. Селен выступает в качестве строительного материала для сборки пептидов, входящих в состав хвостовой части сперматозоидов. Кроме того, селен является неотьемлемым элементом ряда антиокислительных ферментов, обеспечивающих надёжную защиту в условиях интенсификации процессов СРО. 
Проведённое исследование позволяет придти к следующему заключению. В настоящее время считается, что загрязненность внешней среды в значительной степени определяет развитие ряда патологических состояний. Химические канцерогены, вызывая интенсификацию процессов свободнорадикального окисления (СРО), способствуют ускорению процессов старения и развитию болезней, связанных с ним.

Семенник отличается обилием липидов - субстрата ПОЛ. Сперматогенный эпителий относится к быстро пролиферирующим тканям, весьма чувствительным к повреждающему действию продуктов СРО, в связи с чем семенник отличается высоким содержанием таких антиоксидантов (АО), как $\alpha$-токоферол, эрготионеин и аскорбат.

При изучении воздействия сероводородсодержащего газа АГКМ на функциональное состояние семенников белых крыс в наших экспериментах было установлено, что этот токсикант вызывает у крыс стресс-реакцию.

В ткани семенников наблюдалось усиление процессов СРО, что выражалось в увеличении исходной концентрации одного из конечных продуктов ПОЛ - малонового диальдегида (МДА), а также повышении кинетических показателей ПОЛ (спонтанного и аскорбатзависимого ПОЛ). Важнейшим показателем интенсификации процессов СРО в ткани семенников было повышение окислительновосстановительного потенциала гомогената ткани.

При исследовании инкреторной функции семенников в условиях развития окислительного стресса была рассмотрена взаимосвязь между уровнем процессов СРО и секрецией тестостерона. Выяснилось, что однократное воздействие сероводородсодержащим газом вызывает резкое снижение уровня тестостерона в плазме крови. 
В условиях воздействия СВСГ было зафиксировано резкое падение (в 6 раз) уровня лютеинизирующего гормона (ЛГ) в крови. Падение секреции тестостерона положительно и достоверно коррелировало с падением секреции ЛГ (г $=+0,842, \mathrm{P}<0,01)$, что свидетельствует о возможных первичных нарушениях, вызванных экотоксином, в аденогипофизе.

Было также установлено, что под действием СВСГ наблюдалось повышение исходного уровня МДА в гипоталамической ткани, что говорит о нарастании уровня СРО в указанной ткани и, следовательно, о снижении функционального состояния гипоталамуса в целом.

Исходя из всего вышесказанного, представляется логичным допустить, что снижение инкреторной функции семенников является не только результатом непосредственного действия сероводородсодержащего газа на семенники, но и следствием нарушения функционального состояния гипоталамо-гипофизарного комплекса. Подобный вывод подтверждается исследованиями Б.В. Алешина и Л.А. Бондаренко (1982), которые связывают угнетение тестикулярного андрогенопоэза в условиях стресса с усиленной выработкой пролактина и блокадой выброса ЛГ аденогипофизом в кровяное русло. Блокада выброса ЛГ, по мнению авторов, обусловлена, с одной стороны, усилением процессов СРО в гипоталамической ткани, а с другой - повышенной секрецией серотонина, который и тормозит секрецию люлиберина. С другой стороны, нельзя исключить и факта прямого воздействия СВСГ на интерстициальные клетки Лейдига, принимая во внимание факт усиления процессов СРО в самой ткани семенников. Таким образом, под действием СВСГ нарушается функциональная активность как гипоталамо-гипофизарного комплекса, так и семенников; при этом снижение секреции ЛГ в условиях 
окислительного стресса обусловлено, по-видимому, прежде всего нарушением функционального состояния гипоталамуса, что находится в соответствии с концепцией стресса К.В. Судакова (1997) о первичности участия лимбической системы в условиях стресса.

Данные морфологического исследования указывают как на нарушения сперматогенной функции семенников, так и эндокринной под действием СВСГ. Количество гландулоцитов и площадь их ядер не имели существенных отличий от контрольной группы.

Так, в наших опытах $\alpha$-токоферол в физиологических дозах способствовал снижению уровня СРО в ткани семенников. Наблюдалось улучшение функционального состояния семенников, что выразилось в улучшении состояния сперматогенного эпителия, а также вызвало увеличение общего числа клеток Лейдига за счет фукционально наиболее активных средних клеток, площадь которых увеличивалась. Следует отметить взаимосвязь между уровнем СРО и функциональной активностью гонад.

$\alpha$-Токоферол оказывает свое влияние на инкреторную функцию семенников не только непосредственно участвуя в регуляции активности интерстициальных клеток за счет изменения динамики процессов СРО, но и опосредованно через изменение функциональной активности гипоталамо-гипофизарного комплекса. Проведённое исследование показало, что предварительное введение $\alpha$ токоферола в условиях последующего воздействия СВСГ способствовало компенсации процессов СРО в ткани семенников, что в конечном счете означало смягчение токсических эффектов газа в отношении инкреторной и связанной с ней экскреторной функции семенников.

В условиях хронического воздействия СВСГ наблюдается снижение инкреторной функции семенников 
белых крыс. Аналогичная ситуация имеет место и в случае хронического воздействия микроволнового излучения низкой интенсивности. Резкое снижение более чем в 2 раза активности ГСД в условиях воздействия микроволнового излучения свидетельствует о нарушении синтеза тестостерона, что можно объяснить нарушением передачи регуляторных сигналов через изменённую плазматическую мембрану. Наблюдается снижение общего количества сперматогенных клеток в семеннике.

В условиях хронического воздействия СВСГ общее количество сперматогенных клеток снижается в большей степени, чем в случае микроволнового излучения, что указывает на большую выраженность токсических эффектов газа на экскреторную функцию. Вместе с тем, угнетение эндокринной функции в обоих случаях было выражено примерно в равной степени.

В условиях хронической сероводородной интоксикации наблюдалось выраженное нарушение соотношения между сперматогенными клетками. Количество эпидидимальных сперматозоидов заметно снижается. Отмечается увеличение процентного содержания их дефективных форм и мёртвых сперматозоидов.

Таким образом, проведённое исследование позволяет заключить, что и острый, и хронический стресс вне зависимости от его природы вызывает общее угнетение функционального состояния гонад. Определяющую роль здесь должны играть как выраженность окислительных процессов на уровне гонад, так и степень участия гипоталамо-гипофизарного комплекса в регуляции их функционального состояния. Хроническая интоксикация СВСГ вызвала более заметные последствия в отношении половых клеток, чем хроническое воздействие микроволнового излучения миллиметрового диапазона. В качестве компенса- 
торного механизма угнетения инкреторной функции в условиях хронической интоксикации СВСГ можно рассматривать факт разрастания интерстициальной ткани за счёт прироста функционально слабых клеток Лейдига отросчатой формы. Снижение уровня биосинтеза тестостерона в условиях хронического воздействия микроволнового излучения, очевидно, обусловлено структурнофункциональными изменениями биомембран клеток Лейдига. Таким образом, ведущим молекулярным механизмом нарушения функционального состояния гонад в условиях стресса являются изменения на уровне мембранных элементов клеток Лейдига и сперматогенных клеток.

Принимая во внимание то обстоятельство, что и селен, и сера относятся к р-элементам VI группы Периодической системы химических элементов Д.И. Менделеева, можно заключить эти два элемента способны взаимозамещать друг друга при их поступлении в организм. Учитывая то, что в хвосте сперматозоидов содержится селенопептид с $\mathrm{M}=17$ кД, вполне логичным представляется его структурное значение при сборке хвоста сперматозоида (Полунин А.И., Луцкий Д.Л., Мирошников В.М. и др., 2002). Кроме того, селен в качестве компонента антиоксидантной системы участвует в стабилизации мембран сперматозоидов, весьма чувствительных к действию свободных радикалов. Использование селена как протектора в органической форме делает его более биодоступным. Дополнение селена таким водорастворимым антиоксидантом, как витамин С, создаёт необходимые условия для более эффективной коррекции нарушений морфофункционального состояния сперматозоидов в условиях воздействия таких агрессивных стрессирующих факторов, как сероводородсодержащий газ и микроволновое излучение. 


\section{ВЫвОды}

1. Однократное воздействие сероводородсодержащим газом вызывает усиление процессов СРО и повышение окислительно-восстановительного потенциала ткани семенников.

2. Сероводородсодержащий газ АГКМ вызывает резкое падение уровня тестостерона в крови, которое положительно и достоверно коррелирует с ослаблением секреции лютеинезирующего гормона (ЛГ).

3. В условиях однократног воздействия сероводородсодержащего газа имеет место усиление процессов СРО в области медиобазального гипоталамуса, что свидетельствует об угнетении функционального состояния медиобазальной области гипоталамуса и указывает на факт участия гипоталамо-аденогипофизарного комплекса в регуляции функционального состояния семенников в условиях развития окислительного стресса.

4. Однократное воздействие сероводородсодержащим газом АГКМ вызывает выраженные морфофункциональные нарушения ткани семенников белых крыс (интерстициальный отек, гемодинамические нарушения, некроз сперматогенного эпителия).

5. Витамин Е в небольших дозах оказывает:

- выраженный антиоксидантный эффект, значительно подавляя процессы СРО в ткани семенников;

- наряду с антиоксидантным, проявляет пролиферативный и андрогенопоэтический эффекты, что выражается в увеличении количества гормонпродукцирующих интерстициальных клеток и площади их ядер;

- стимулирующий эффект на сперматогенную функцию семенников (увеличение высоты сперматогенного эпителия, увеличение относительной массы гонад).

6. Предварительное введение $\alpha$-токоферола снижает ток- 
сические эффекты сероводородсодержащего газа АГКМ на гипоталамо-гипофизарно-гонадную систему самцов крыс. Отмечается нормализация уровня тестостерона и ЛГ в крови.

7. Хроническое воздействие сероводородсодержащим газом вызывает угнетение тестикулярного андрогенопоэза, о чём свидетельствует снижение общей активности $\Delta^{5}$-3 $\beta$-гидроксистероиддегидрогеназы (ГСД) в гомогенатах семенников более чем в 2 раза в сравнении с контролем $(\mathrm{P}<0,001)$. Наблюдается резкое снижение сперматогенных клеток и выраженное нарушение соотношения между различными типами сперматогенных клеток.

8. Количество эпидидимальных сперматозоидов в условиях хронической сероводородной интоксикации снижается более чем в 1,7 раз. В популяции сперматозоидов отмечается увеличение процентного содержания дефективных форм и резкое увеличение количества мёртвых сперматозоидов.

9. Хроническое воздействие микроволнового излучения низкой интенсивности вызывает угнетение тестикулярного андрогенопоэза. Наблюдается снижение общего количества сперматогенных клеток в семеннике и дисбаланс между разными типами сперматогенных клеток. Степень же выраженности токсических эффектов была заметно ниже в отношении сперматогенных клеток, по сравнению с таковой в случае хронического воздействия сероводородсодержащим газом.

10. Использование селенсодержащего биокомплекса в качестве корректора в условиях хронического воздействия сероводородсодержащего природного газа и микроволнового излучения низкой интенсивности способствует значительному снижению токсических эффектов, 
вызываемых последствиями развития окислительного стресса. В целом отмечается улучшение двигательных свойств эпидидимальных сперматозоидов, по сравнению с таковыми у животных, подвергавшихся воздействию указанных стресс-факторов. Семенные канальцы имеют тенденцию сохранения своей морфофункциональной организации аналогичной таковой в контрольной группе.

\section{Внедрение результатов работы в практику}

Результаты исследования используются в научных исследованиях и практической работе:

- кафедры химии ГБОУ ВПО «Астраханский государственный медицинский университет» Минздрава России;

- Центра планирования семьи и репродукции человека г. Астрахани;

- Научно-производственного медицинского комплекса «Экологическая медицина» ООО «Астраханьгазпром».

Результаты проведённого исследования используются в качестве учебного материала для студентов, интернов и ординаторов Астраханского государственного медицинского университета. 


\section{ПРИЛОЖЕНИЕ}

\section{Патологии, связанные с недостатком и избытком цинка}

I. Токсичность цинка. В целом цинк нетоксичный. Избыточное поглощение цинка может подавить поглощение меди и железа. Ион свободного цинка в растворе высоко токсичен для растений, беспозвоночных и даже рыб. Гомеостаз цинка регулируется прежде всего через посредство пищеварительной системы за счёт процесса поглощения экзогенного цинка, а также пищеварительной секреции и экскреции эндогенного цинка.

\section{II. Цинкдефицитные состояния}

1. Антенатальный (пренатальный) период.

Уже эмбрион и плод в критические периоды своего развития чувствительны к недостатку цинка в организме матери. Возникающие при этом цинкдефицитные состояния ведут к рождению незрелого плода, а также формированию различных патологий (расщепление нёба, пороки сердца).

2. Постнатальный (после рождения) период

1) Эндогенный дефицит цинка (при врождённых и генетических заболеваниях):

a) энтеропатичсеский акродерматит (это прогрессивное нарушение метаболизма цинка у маленьких детей, часто вначале проявляется в виде пузырчатой и корковой сыпи на конечности, после чего следует потеря волос и желудочно-кишечные нарушения) - нарушение биосинтеза белка-лиганда для связывания, всасывания и транспорта металла;

б) клинические формы серповидно-клеточной анемии, сопровождающиеся цинкурией.

2) Экзогенный дефицит цинка:

a) алиментарная недостаточность:

(i) симптомокомплекс железодефицитной анемии с карликовостью и половым недоразвитием;

(ii) преждевременные роды и врождённые уродства, слабость родовой деятельности (женщины, испытывающие недостаток цинка во время беременности);

б) при заболеваниях:

(i) желудочно-кишечного тракта (хронический гастрит, колит);

(ii) печени (алкогольный цирроз).

3) Ятрогенный дефицит цинка (лечение ожирения гистидином). 
Широкое разнообразие продуктов содержит цинк. Устрицы содержат много цинка. В то же самое время красное мясо и птица обеспечивают значительное количество цинка. Другие хорошие источники пищи включают в себя бобы, орехи, определённые виды морепродуктов (например, крабы и омары).

\section{ПРЕДМЕТНЫЙ УКАЗАТЕЛЬ}

Антиоксиданты 24

Аскорбиновая кислота 21, 22, 52, 62

Гидроксистероиддегидрогеназа (ГСД) 11

Гипоталамус 14, 65

Гипофиз 13

Глутатионпероксидаза 28

Гонадолиберин 13

Дофамин 14

Лейдига клетки 10

Лютеинизирующий гормон 13, 33

Малоновый диальдегид (МДА) 32, 35, 36

Микроволновое излучение 41, 67

Перекисное окисление липидов (ПОЛ) 17

Селен 51

Селенопротеин 25, 26

Семенники 22

Сероводородсодержащий газ 22, 67

Серотонин 14

Сертоли клетки 10

Сперматогенез 15, 48

Сперматозоиды 12

Сперматогонии 12, 42, 47

Тестостерон

Токоферол 10, 11

Фолликулостимулирующий гормон (ФСГ) 13

Цинк 25, 71

Эпидидимальные сперматозоиды 50 


\section{Список литературы}

1. Авцын, А. П. Микроэлементозы человека / А. П. Авцын, А.А. Жаворонков, М. А. Риш, Л. С. Строчкова. - М. : Наука, 1991. -495 с.

2. Алешин, Б. В. К механизму нарушения андрогенопоэза при стрессе / Б. В. Алешин, Л. А. Бондаренко // Бюллетень экспериментальной биологии и медицины. - 1982. - Т. 94, № 7. - С. 98-100.

3. Асфандияров, Р. И. Острые отравления серосодержащими газами / Р. И. Асфандияров, В. Н. Бучин, А. Е. Лазько и др. - Астрахань : Волга, 1995. - 156 с.

4. Беледа, Р. В. Зависимость половой конституции и частоты половых расстройств от гормонального статуса при хроническом простатите Р. В. Беледа, M. А. Михалёв // 8-й Российский научнообразовательный форум «Мужское здоровье и долголетие», Москва, 17-18 февраля 2010 г. - М.: ВК «РИМИЭКСПО», 2010. - С. 29-30.

5. Бобырев, В. Н. Специфичность систем антиоксидантной зашиты органов и тканей - основа дифференцированной фармакотерапии антиоксидантами / В. Н. Бобыре, В. Ф. Почерняева, С. Г. Стародубцев и др. // Экспериментальная и клиническая фармакология. - 1994. - Т. 57, № 1. - С. 47-54.

6. Булыгина, В. В. Влияние хронического стресса в препубертатном периоде на проявление половой активации у взрослых самцов крыс В. В. Булыгина, Т. Г. Амстиславская, Л. Н. Маслова и др. // Российский физиологический журнал им. И.М.Сеченова. - 2001. - Т. 87, № 7. - С. 945-952.

7. Дмитриев, Л. Ф. Влияние $\mathrm{pH}$ и глутатиона на перекисное окисление липидов в микросомах, обогащенных токоферолом / Фармакология и токсиколо- 
гия / Л. Ф. Дмитриев, М. В. Иванова, А. В. Лебедев // Бюллетень экспериментальной биологии и медицины. - 1995. - Т. СХХ, № 9. - С. 268-270.

8. Дмитриев, Л. Ф. О механизме взаимодействия токоферола с перикисными радикалами / Л. Ф. Дмитриев, М. И. Верховский // Биохимия. - 1990. - Т. 55, вып. 11. - С. 2025-2030.

9. Евдокимов, В. В. Витаминный статус и сперматогенез крыс в поздние сроки после облучения разными дозами / В. В. Евдокимов, В. М. Коденцова, Л. Ф. Курило и др. // Бюллетень экспериментальной биологии и медицины. - 1999. - Т. 128, № 7. - С. 42-44.

10. Имелинский, К. Сексология и сексопатология / К. Имелинский. - М.: Медицина, 1986. - 424 с.

11. Лакин, Г. Ф. Биометрия: Учебное пособие для биол. спец. вузов / Г. Ф. Лакин. - М.: Высшая школа , 1990. - $352 \mathrm{c}$.

12. Луцкий, Д. Л. Иммунохимическая и биохимическая характеристика спермоплазмы субфертильных мужчин: автореферат дис. ... канд. мед. наук / Д. Л. Луцкий. - М., 2000. -28 с.

13. Луцкий, Д. Л. Способ оценки воздействия неблагоприятных экологических факторов на репродуктивную функцию мужчин / Д. Л. Луцкий, А. А. Николаев // Клин. лаб. диагностика. - 2000. - № 10. - С. 42-43.

14. Мажитова, М. В. Физиологический уровень перекисного окисления липидов в гипоталамусе, больших полушариях мозга, печени и его модификация стресс-индуцирующими агентами и $\alpha$-токоферолом: автореф. дис. ... канд. биол. наук / М. В. Мажитова. - Астрахань, 2000. 
15. Мамина, В. П. Метод определения количества сперматогенных клеток семенника в клеточной суспензии / В. П. Мамина, Д. И. Семенов // Цитология. 1976. - Т. 18, № 7. - С. 913-914.

16. Милютина, Н. П. Антирадикальный и антиоксидантный эффект аргинина и его влияние на активность перекисного окисления липидов при гипоксии / Н. П. Милютина, А. А. Ананян, В. С. Щугалей // Бюллетень эксп. биол. и медицины. - 1990. - № 9. C. 263-265.

17. Овсянникова, Т. Н. Влияние физической нагрузки и температуры на метаболизм семенников. / Т. Н. Овсянникова, В. В. Лемешко // Научн. сов. АН СССР и АМН СССР по физиол. наукам: 4 Всесоюзная конф. «Эндокринная система организма и вредные факторы окружающей среды», 15-19 сентября 1991 г. Тезисы докладов - Л., 1991. - С. 174.

18. Плосконос, М. В. Определение полиаминов в различных биологических объектах / М. В. Плосконос, А. А. Николаев, А. А. Николаев. - Астрахань: АГMA, 2007. $-119 \mathrm{c}$.

19. Полинг, Л. Витамин С и здоровье / Л. Полинг. - М. : Наука, 1974. - 74 с.

20. Полунин, А. И. Селен и цинк в коррекции мужской субфертильности: Учебное пособие для врачей / А. И. Полунин, Д. Л. Луцкий, В. М. Мирошников, А. А. Николаев. - Астрахань : АГМА, 2002. - 42 с.

21. Пюрведжалова, Э. Б. Влияние разных доз витамина Е на печень разнополых белых крыс в норме и при действии сероводородсодержащего газа астраханского газоконденсатного месторождения: автореф. дис. ... канд. биол. наук / Э. Б. Пюрведжалова. - Астрахань, 2004. -23 с. 
22. Райцина, С. С. Сперматогенез и структурные основы его регуляции / С. С. Райцина. - М., 1985.

23. Резніков, О. Г. Определение активности гидроксистероиддегидрогеназы / О. Г. Резніков, В. М. Демченко, О.В. Нищименко // Фізіол. журн. - 1976. - № 5. - C. 616-621.

24. Ронин, В. С. Руководство к практическим занятиям по методам клинических лабораторных исследований / В. С. Ронин, Г. М. Старобинец. - М., 1989. $320 \mathrm{c}$.

25. Саноцкий, И. В. Незаменимый селен / И. В. Саноцкий. - М. : Ассоциация АКМ, 2001. - 96 с.

26. Саноцкий, И. В. Отдалённые последствия влияния химических соединений на организм / И. В. Саноцкий, В. Н. Фоменко. - М. : Медицина, 1979. - 232 с.

27. Скальный, А. В. Макро- и микроэлементозы в физической культуре и спорте / И. В. Скальный, 3. Г. Орджоникидзе, О. А. Громова. - М. : Медицина, 2000. - $71 \mathrm{c}$.

28. Скальный, А. В. Микроэлементозы человека (диагностика и лечение): практическое руководство для врачей и студентов медицинских ВУЗов / А. В. Скальный. - М. : КМК, 1999. - 96 с.

29. Скрыпин, В. И. Взаимодействие $\alpha$-токоферола со свободными жирными кислотами. Пространственная организация комплекса / В. И. Скрыпин, А. Н. Ерин, В. Е. Каган и др. // Бюллетень экспериментальной биологии и медицины. - 1986. - № 6. - С. 682-684.

30. Слесарев, В. И. Химия: Основы химии живого: учебник для вузов / В. И. Слесарев. - 4-е изд., испр. - СПб. : Химиздат, 2007. - 784 с. 
31. Созавшвили, Ш. Т. Состояние роста, развития, плодовитости и С-витаминного обмена в половых органах и железах внутренней секреции у крыс при гипервитаминозе Е / Ш. Т. Созашвили // В кн.: Тр. НИИ физиологии и патологии женщины. Тбилиси, 1970. - Т. 5. - С. 269-273.

32. Стальная, И. Д. Метод определения малонового диальдегида с помощью тиобарбитуровой кислоты / И. Д. Стальная, Т. Т. Гаришвили // Современные методы в биохимии. - М.: Медицина, 1977. - С. 66-68.

33. Строев, Е. А. Практикум по биологической химии / Е. А. Строев, В. Г. Макарова - М.: Высшая школа, 1986. - C. 211-214.

34. Судаков, К. В. Новые акценты классической концепции стресса / К. В. Судаков // Бюл. экспер. биол. и медицины. - 1997. - Т. 123, № 2. - С. 124-130.

35. Тёплый, Д. Л. Влияние витамина Е на нейросектреторные клетки гипоталамуса белых крыс / Д. Л. Тёплый // Цитология. - 1990. - Т. 32, № 12. - С. 1161 1167.

36. Тёплый, Д. Л. Исследование влияния витамина Е на функциональные системы организма: дис. докт. биол. наук / Д. Л. Тёплый. - Ленинград, 1984. - 583 c.

37. Тиктинский, О. Л. Андрология / О. Л. Тиктинский, В. В. Михайленко. - СПб., 1999.

38. Тюрин, В. А. Взаимодействие $\alpha$-токоферола с фосфолипидными липосомами: отсутствие трансбислойной подвижности / В. А. Тюрин, В. Е. Каган, Е. А. Сербинова и др. // Бюл. экспер. биол. и медицины. - 1986. - № 12. - С. 689-692.

39. Ушакова, М. В. Функционирование репродуктивной системы самцов крыс при хроническом воздействии 
природных токсикантов: автореферат дис. ... канд. биол. наук / М. В. Ушакова. - Астрахань, 2002. - 22 c.

40. Чичинадзе, К. Механизмы регуляции полового поведения / К. Чичинадзе // Проблемы эндокринологии. - 2004. - Т. 50, № 1. - С. 47-49.

41. Шевлюк, Н. Н. Ультраструктурное исследование интерстициальных эндокриноцитов семенников сусликов из популяции, обитающей в санитарной зоне Оренбургского газоперерабатывающего завода / Н. Н. Шевлюк // Влияние антропогенных факторов на структурные преобразования органов, тканей, клеток человека и животных. - Саратов, 1993. - Ч. 4. - C. 95.

42. Behne, D. Studies in the distribution and characteristics of new mammalian selenium-containing proteins / D. Bebne, C. Weiss-Nowak, M. Kalcklösch et al. // Analyst. - 1995. - Vol. 120, № 3. - P. 823-825.

43. Bremner, W. J. Immunohistochemical localization of androgen receptors in the rat testis: evidence for stagedependent expression and regulation by androgens / W. J. Bremner, M. R. Millar, R. M. Sharpe et al. // Endocrinology. - 1994. - Vol. 195, № 3. - P. 1227-1234.

44. Gallo, R. V. Effect of electrochemical stimulation of the ventral hippocampus on hypothalamic electrical activity and pituitary gonadotropin secretion in female rats / $\mathrm{R}$. V. Gallo, J. H. Johnson, B. D. Goldman // Endocrinology. - 1971. - Vol. 82. - P. 704-743.

45. Loembeck, I. Selenium intake of infants and young children, healthy children and dietetically treated patients with phenylketonuria / I. Loembeck, K. H. Ebert, K. Kasperek et al. // Europ. J. Pediat. - 1984. - Vol. 143, № 2. - P. 99-102. 
46. Makanji, Y. Suppression of inhibin A biological activity by alterations in the binding site for betaglycan / Y. Makanji, K. L. Walton, M. C. Wilce et al. // The Journal of Biological Chemistry. - 2008. - Vol. 283, № 24. - P. 16743-16751.

47. Marcus, M. F. Electrochemical Studies of the Redox Behavior of $\alpha$-Tocopherol / M. F. Marcus, M. D. Hawley // Biochem. et biophys. acta. - 1970. - Vol. 201. P. 1-8.

48. Motsenbocker, M. A. Effect of dietary selenium on plasma selenoprotein $\mathrm{P}$, selenoprotein $\mathrm{P} 1$ and glutathione peroxidase in the rat / M. A. Motsenbocker, A. L. Tappel // J. Nutr. - 1984. - Vol. 114, № 2. - P. 279285.

49. Persky, H. Androgens and sexual behavior of women / H. Persky, H. J. Lief, D. Strauss // Third Intern. Congress Med. Sexology. - Rome, 1978.

50. Sato, Y. Effects of long-term psychological stress on sexual behavior and brain catecholamine levels / Y. Sato, N. Suzuki, H. Horita et al. // J. Androl. - 1996. Vol. 17, № 2. - P. 83-90.

51. Sharaf, A. Androgenicity in vitamins / A. Sharaf, N. Gomaa // Qualitas plantarum et material vegetabiles. 1970. - Vol. 19, № 4. - P. 369-374.

52. Underwood, E. G. Trace elements in human and animal nutrition / E. G. Underwood. $-4^{\text {th }}$ ed. - New York : Acad. Press, 1977. - 179 p.

53. Yousef, M. I. Effect of ascorbic acid and vitamin E supplementation on semen quality and biochemical parameters of male rabbits / M. I. Yousef, G. A. Abdallah, K. I. Kamel // Anim. Reprod. Sci. - 2003. Vol. 76, № 12. - P. 99-111. 


\section{ЛОГИНОВ ПАВЕЛ ВАДИМОВИЧ,}

кандидат биологических наук (Ph.D),

доиент кафедры химии, профессор РАE ГБОУ ВПО «Астраханский государственный медицинский университет» Минздрава России

\section{НИКОЛАЕВ АЛЕКСАНДР АРКАДЬЕВИЧ,} доктор медицинских наук, профессор, заведуюший кафедрой химии, член-корреспондент РAE, Заслуженный работник науки и образования ГБОУ ВПО «Астраханский государственный медииинский университет» Минздрава России

\section{СЕЛЕН В КОРРЕКЦИИ РЕПТРОДУКТИВНОЙ ФУНКЦИИ ПРИ СТРЕССЕ}

Учебно-методическое пособие

Компьютерный набор - Логинов П.В. Форматирование и корректура - авторские Технический редактор - Нигдыров В.Б.

Подписано в печать

Формат $60 \times 90$ 1/16. Бумага офсетная. Гарнитура Times New Roman

Усл. печ. лист. - 4,7; Уч.-изд. л. - 2,25. Тираж 300. Заказ №

Изд-во Астраханского государственного медицинского ун-та 414000, Астрахань, ул. Бакинская, 121. 